Review Article

\title{
HYMENOPTERA TOXINS: BIOLOGICAL ACTIVITY, PHARMACEUTICAL AND THERAPEUTIC USES
}

\author{
SIMRAN SHARMA, RAVI KANT UPADHYAY \\ Department of Zoology, Deen Dayal Upadhyaya Gorakhpur University, Gorakhpur \\ Email: rkupadhya@yahoo.com
}

Received: 09 Dec 2020, Revised and Accepted: 09 Feb 2021

\begin{abstract}
The present review article explains the salient features of hornet venom toxins, their physiological, biological and pharmacological effect on animals and man. Hornets sting very fast and inflict venom, which is more dangerous than those of bees. Hornet venom contains both proteinaceous and non-proteinaceous peptides i.e. scapin, adolapin, mellitin, mastoparans and enzymes, mainly phospholipase and hyaluronidase, which show multiple biological effects i.e. cytolytic, hemotoxic, neuro-inhibitor, anticancer, anti-parasitic, immune hypersensitive, inflammatory, antimicrobial and anti-insect activities. Hornet stings are more painful to humans than typical wasp stings because hornet venom contains a large amount (5\%) of acetylcholine. Hornet toxin components interact with receptors, ion channels and gated channels and affect the permeability functions of cells. Heavy envenomation shows quick pathophysiological lethal effects in man and pet. This article emphasizes the use of various hornet venom components for the production of disease-modifying anti-rheumatic and analgesic, anticancer drugs and insecticides. Hornet venom allergens could be used to prepare the rational design of component-resolved diagnosis of allergy and venom immunotherapy of inflicting patients.
\end{abstract}

Keywords: Hornets stings, Venom and toxin, Anticancer activity, Anti-parasitic, Immune hypersensitivity activities

(C) 2021 The Authors. Published by Innovare Academic Sciences Pvt Ltd. This is an open access article under the CC BY license (https://creativecommons.org/licenses/by/4.0/) DOI: https://dx.doi.org/10.22159/ijpps.2021v13i4.40473. Journal homepage: https://innovareacademics.in/journals/index.php/ijpps.

\section{INTRODUCTION}

The hornets are hymenopteran insects belonging to genus Vespa. These are the largest social wasps, show similar appearance to their close relative's yellow jacket wasps. Like wasps, hornets are also found almost in all parts of the world. The Asian giant hornet (Vespa mandarinia) is the world's largest social wasp builds communal nests by chewing wood to make a papery pulp. Most of their species are flower visitors and collect nectar in the morning hours. The hornets are mostly of black to light black color and their size ranges 4.3 to $5.5 \mathrm{~cm}(2.2 \mathrm{in})$ in length. They are distinguished from other vespine wasps by the relatively large top margin of the head and by the rounded segment of the abdomen just behind the waist. Hornets use stings to kill prey and defend hives. Hornet stings are more painful to humans than typical wasp stings because hornet venom contains a large amount of acetylcholine. Individual hornets can sting repeatedly, unlike honey bees; these do not die after stinging because their stingers are very finely barbed (only visible under high magnification) and can easily be withdrawn and so are not pulled out of their bodies when disengaging. The hornets are giant natural predators and play an important role in the balance of natural ecosystems through pollination, natural pest control and biodiversity [1].

Hornet species found in Asia shows similarity in behavior and genetics to European hornet (Vespa crabo). This species is widely distributed throughout Europe, Russia, North America and Northeast Asia. Wasps native to North America belong to genus Dolichovespula are bald-faced hornets, but really they are actually yellow jacket wasps. So far, over 30,000 species of hymenopteran wasps have been reported, among which hornet biodiversity. Worldwide, shows 22 recognized species of genus Vespa [2]. The most common types of wasps or hornets, they build nest, which is housed by one queen, who lays eggs and is attended by workers. Workers are genetically sterile, cannot lay eggs. Most species make exposed nests in trees and shrubs, but some like Vespa orientalis build their nests underground or in wood or mud cavities. In the tropics, these nests may last year-round, but in temperate areas, the nest dismantle over the winter, with lone queens hibernating in leaf litter or other insulative material until the spring. Hornets are often considered pests, as they aggressively guard their nesting sites when threatened and their stings can be more dangerous than those of bees [3] (table 1).

\section{Source of information}

For writing this comprehensive research review on hymenopteran toxins/allergens, various databases were searched. For the collection of relevant information, specific terms such as medical subject headings (MeSH) and key text words, such as "venom allergens", "biological and pharmaceutical effects", therapeutic uses" published till 2020 were used in MEDLINE. Most especially for retrieving all articles pertaining to the use of VIT for insect venom allergy, electronic bibliographic databases was searched and abstracts of published studies with relevant information on the venom toxins/allergens were collected. Furthermore, additional references were included through searching the references cited by the studies done on the present topic. Relevant terms were used individually and in combination to ensure an extensive literature search. For updating the information about a subject and incorporation of recent knowledge, relevant research articles, books, conference proceedings and public health organization survey reports were selected and collated based on the broader objective of the review. This was achieved by searching databases, including SCOPUS, Web of Science, and EMBASE, Pubmed, PMC, Publon, Swissprot, Google searches" From this common methodology, discoveries and findings were identified and summarized in this final review.

\section{Venom composition}

Hymenoptera venom is a complex mixture of many substances such as toxins, enzymes, growth factor activators, and inhibitors (table 1 , fig. 1). These are bioactive agents which impose deleterious effects in cells and tissues after venom infliction. Parasitic solitary wasps use bioactive venom components with the functions of prey inactivation and physiology manipulation. Wasp, bee and hornet toxins, mainly proteins, show hemolytic and immunestimulatory effects (table 1). Venom of Neoponera villosa induces hemolysis in human erythrocytes and also induced release of both pro-inflammatory cytokines, as the anti-inflammatory cytokine release by murine macrophages [4]. The various Vespa species venom contains kinins, polyamines and hornetin, which showed cytotoxic and anticancer activities (table 1). Vespa vulagaris secrete hyluronidase A an enzyme that is highly allergenic and shows cytotoxic activity. Bees also secrete acid phosphatase that acts as a 
coagulation factor and show antimicrobial activity (table 1, fig. 1). Hornet venom contains enzyme phospholipase, acid phosphatase, and various phospholipases, appear to be relatively more specific to the social wasp venom (table 1). Hornet venom binds to a large number of proteins and receptors and imposes pathophysiological changes in victims. These enzymes cause the disruption of cellular membranes and induce hypersensitive reactions, including life threatening anaphylaxis. Moreover, phospholipase A2 is a major component of bee venoms, while phospholipase A1 (PLA1) is highly abundant in wasps and ants. Common components in both solitary and social wasp venoms include hyaluronidase, phospholipase A2, metalloendopeptidase (table 1, fig. 1). These enzymes trigger an immune response, inducing IgE response in susceptible individuals [5]. Some neurotoxic peptides (e. g., pompilido toxin and dendrotoxin-like peptide), proteins (e. g., insulin-like peptidebinding protein) and allergens also found in solitary wasp venom. Similar to venom found in most venomous animals, parasitoid venoms contain a complex cocktail of proteins with potential agrochemical and pharmaceutical use (table 1, fig. 1).

\section{Enzymes}

\section{Phospholipase B (PLB)}

Phospholipase B (PLB), also known as lysophospholipase, is an enzyme found in very low concentrations in hornet venoms. Phospholipase A2 (PLA2) is a calcium-dependent enzyme that hydrolyzes the Sn-2 ester of glycerol phospholipids to produce a fatty acid and a lysophospholipid. It destroys phospholipids, disrupting the integrity of the lipid bilayers, thus making cells susceptible to further degradation. In fact, PLA2 reaction products, such aslysophosphatidyl choline, lysophosphatidic acid and sphingosine 1-phosphate, can have cytotoxic or immune stimulatory effects on diverse cell types, causing inflammation and immune responses [6]. With the capacity to cleave acyl chains from both sn-1 and sn-2 positions of a phospholipid, PLB shows a combination of PLA1 and PLA2 activities. Hyaluronidase is commonly known as a "spreading factor" because it hydrolyzes the viscous polymer hyaluronic acid into non-viscous fragments. It also acts as an allergenic agent (table 1; fig. 1). When an extracellular matrix is destroyed by hyaluronidase, the gaps between cells facilitate the invasion of venom toxins (fig. 1). Therefore, venom penetrates in tissues and enters blood vessels, thus catalyzing systemic poisoning. Furthermore, hydrolyzed hyaluronan fragments are pro-inflammatory, pro-angiogenic and immune stimulators, thus inducing faster systemic envenomation [7].

\section{Mast cell degranulating (MCD) peptide}

Mast cell degranulating (MCD) peptide is cationic in nature, having 22 amino acid residues. It shows a similar structure to albumin. It is cross-linked by two disulphide bond [8]. This peptide is a potent anti-inflammatory agent; at low concentration, it is a strong mediator of mast cell degranulation and histamine release from mast cells, which are present in the blood supply and in all tissues perfuse by blood [9] (table 1; fig. 1).

\section{Bradykinin}

Bradykinin is a physiologically active peptide that belongs to the kinin group of proteins. Bradykinin and related kinins act on two receptors, designated as B1 and B2 (table 1). The former is expressed only as a result of tissue injury and it is thought to play a role in chronic pain. In contrast, the B2 receptor is constitutively expressed, participating in vasodilatation via the release of prostacyclin, nitric oxide, and endothelium-derived. Hyperpolarizing factor contributes lower blood pressure [10] (table 1; fig. 1).

\section{Adolapin}

Adolapin is a peptide that exerts a potent analgesic and antiinflammatory effect in rats and blocks prostaglandin activity [11]. Tertiapin, also from bee venom, is a 21 amino acid peptide that blocks certain types of inwardly rectifying potassium channels [12] (table 1; fig. 1).

\section{Scapin A}

The peptides Scapin-1, and Scapin- 2 are all 25 amino acid residues in length and share a similar secondary structure, with a disulfide bridge between Cys 9 and Cys 20. These peptides have been isolated from the venom various species, such as Scapin from European Apis mellifera [13]. Scapin-1 from Chinese Apis mellifera [14] and scapin-2 have been isolated the Africanized honey bee [15] (fig. 1, table 1).

\section{Apamin}

Apamin is bee venom peptide that acts as a neurotoxin and induces multiple physiological effects. Albumin acts mainly on the CNS. It blocks $\mathrm{Na}+\mathrm{K}+$ channels; in neurons and binds with high affinity to post-synaptic membrane receptors and causes hyper-polarization of adrenergic, cholinergic and purinergic nerve fibers. It also generates neurotensin-induced effects and blocks post-synaptic functions but does not show any lytic activity in mammalian cells [16] (table 1).

\section{Proteases}

Protease is an enzyme having high levels of proteolytic activity in connective tissues [17] and cause moderate necrosis [18]. It also occurs in venom of social wasp (Polistes infuscatus), Vespa orientalis [19] Polybia paulista, Polybiaignobilis, Agelaia pallipes pallipes, Apoica pallens and ant (Eciton burchelli) [20]. These insects also contain several isoenzymes, which are responsible for caseinolytic and gelatinolytic activities [21]. Bombus venom protease in association with PLA2, HYAL, and acid phosphatase havetrypticamidase specificity and having strong allergenic reactions. Bombus species such as Bombus impatiens, Bombus fraternus, and Bombus bimaculatus also exhibit trypticamidase activity [22], coagulant, [23] and hemorrhagic activities [24] (table 1).

\section{Mastoparan-C (MP-C)}

Wasp venoms also contain small molecules, such as minerals, amino acids, and physiologically active amines, such as catecholamines. Histamine is a major organic nitrogenous compound found in wasp venom that participates in the inflammatory response by increasing the permeability of capillaries. Few species of wasps such as Ropalidia,Vespa xanthoptera, Vespa ducalis and Vespula lewisii secrete mastoparan molecules that cause allergic inflammation and does mast cell degranulation in mammals (table 2, fig. 2). Different species of Yellowjacket wasps i.e. Vespa flavopilosa, Vespula vidua, Vespula lewisii, Vespula pensylvanica and Vespula squamosa secrete allergen 5 in their venoms which show anticancer activity (table 2,

fig. 2). In addition, Vespa orientalis, Paravespula maculifrons, Vespa xanthoptera and paper wasp Polistes exclamans kinins are responsible for severe pain production and act as neuro-inhibitors (table 2, fig. 2).

Catecholamines, dopamine and nor-adrenaline increase heartbeat, thereby enhancing venom circulation and thus, its distribution [25]. Serotonin is a strong irritant that evokes contribute pain caused by venom. Finally, high levels of Acetylcholine increase perceived pain of a sting by stimulating pain receptors synergically with histamine effects. The black-bellied hornet (Vespa basalis) possesses highly toxic venom which is rich in toxin, enzymes and biologically active peptides. It also contains mastoparan B, protease and serotonin, which showed chemotactic activity on human neutrophils. These peptides also exhibit potent hemolytic activity. Serotonin imposes an edematous effect on victims. Mastoparan B is a cationic tetra decapeptide isolated from Vespa basalis show strong edematous and hemolytic activities. This hemolytic and edema-inducing activities of MP-B, is due to presence of Lys2 amino acid and Trp9 rupture membrane and generate hemolytic activity [26] (table 2, fig. 2).

\section{Biological activities}

Hymenopteran insects inflict a large amount of venom in the victim that causes massive inflammation, swelling and pain. It obstructs respiration due to extensive swelling of the tracheal region [27] and how very high lethality and systemic reactions after envenomation [28]. Usually, bees stung victims survived high in number [29] but sometimes stinging occurs in the neck region blocks respiration due to tracheal swelling. Severity of venom increase with increases in the quantity of venom injected [30]. Lethality increases with the age [31, 32 ] venom toxin hardly acts upon liver and kidney cells that make 
metabolic alterations in the body [33], B lymphocytes, secrete a group of immunoglobulins and release $\gamma$ interferons. Each immunoglobulin released from B-lymphocyte recognizes different epitopes and bind selectively [34-38]. Melittin is a major toxic component found in bee venom show diverse biological activity [39] (table 3, fig. 3). Similarly, venom of A. dorsata, A. serene and A. florae exhibited nearly identical lethal dose $[40,41]$. Hornets deliver just a typical insect sting, while others are among the most venomous known insects. Single hornet stings are not in themselves fatal, except sometimes to allergic victims. Individual hornets can sting repeatedly; unlike honey bees, hornets do not die after stinging because their stingers are very finely barbed (only visible under high magnification) and can easily be withdrawn and so are not pulled out of their bodies when disengaging. Hornet venom imposes allergen-specific reactions and also regulates immune responses and makes physiological changes [42] (table 3, fig. 3).

Hornet stings are more painful to humans than typical wasp stings because hornet venom contains a large amount (5\%) of acetylcholine (table 2). Hornets attack very fast in groups and use stings to kill prey and defend hives. Asian giant hornet (Vespa mandarinia) inflicts venom very quickly and cause human fatalities in Asian countries [43]. Its toxicity depends on the sting and and volume of venom injected into the host, and varies according to hornet species. Asian giant hornet venom can cause allergic reactions and multiple organ failure leading to death, though dialysis can be used to remove the toxins from the bloodstream. Allergic reactions are commonly treated with epinephrine (adrenaline) injection using a device such as an epinephrine auto-injector, with prompt follow-up treatment in a hospital. In severe cases, allergic individuals may go into anaphylactic shock and die unless treated promptly [44]. Hornets possess black and white with yellow head strips. Single hornet stings are not in themselves fatal, they cause allergic reactions in victims [45].

Peptides isolated from bees and wasps i.e. tropomyosin from Orancistro cerus, drewsen, iRhynchium brunneum, paramyosin from Orancistro cerus drewseni, Rhynchium brunneum, myosin from Eumenes pomiformis affect muscle contraction and assembly of contractile machinery in muscle cells (table 3; fig. 3). Chemotactic peptide and mastparan like peptide secreted from Cyphononyx fulvognathus wasp venom showed inflammatory activity due to the presence of kinins and polymanines (table 3; fig. 3). Eumenes pomiformis secrete dendrotoxin that is responsible for $\mathrm{K}^{+}$channel blocking, while Anopliussa mariensis secrete $\alpha$-pompilidiotoxin, Batozonellus maculifrons $\beta$-pompilidiotoxin cause paralysis and block $\mathrm{Na}^{+}$channels (table 3; fig. 3). Vespa affinis stings cause complications such as myocardial infarction and multiple organ failure. Hornet toxins, increase microvascular permeability and acute pulmonary edema as the primary pathology after envenoming (table 3; fig. 3). Early recognition of acute pulmonary edema in hornet stings is needed more appropriate diagnosis, more often highquality treatments to avert deaths (table 3).

The wasp, Agelaia pallipes pallipes is one of the most aggressive species the Neotropical region, causing many stinging accidents every year, characterized by severe envenoming reactions. These peptides presented activity related to mast cell degranulation, hemolysis, or even the chemotaxis of leukocytes [46]. The P. paulista venom contains eightyfour venom proteins. The wasp stings action starts with the diffusion of venom through the tissues and and to the blood, it is followed by tissue hemolysis, inflammation, and allergy-played by antigen-5, PLA1, hyaluronidase, HSP 60, HSP 90, and arginine kinases [47]. Peptides isolated from the venoms of the honey bee (Apis mellifera) and the social wasps Polybia paulista and Proto nectar in asylveirae showed nociceptive (hyperalgesic) and edematogenic effects. Its venom possesses peptides Melittin (Apis mellifera), Polybia-MP-I, N-2-PolybiaMP-I N-2-Polybia-MP-I (Polybia paulista), protonectarina-MP-NH2 and Protonectarina-MP-OH (Protonectar in a sylveirae) [48] (table 3; fig. 3).

Hymenopteran stings induce uncontrolled inflammation that results in extensive tissue damage and IgE-mediated hypersensitivity reactions. Venom allergens cause local reactions to severe pain and intense pain. [49]. Inflammatory response initiates with the release and activation of pro-inflammatory cytokines and other mediators, such as nitric Oxide. Cytokines play important roles in mediating cell recruitment and activation necessary for inflammation and repair of tissue damage. Few lepidopteran insects impose allergic urticaria dermatitis and atopic asthma, coagulopathy, renal failure, and intra cerebral hemorrhage [50]. Eicosanoids mediate inflammation. Melittin acts as an antiinflammatory drug as they have the capacity to inhibit PLA2 activity [51].]. It behaves much better than non-steroidal drugs, methotrexate, and other biological disease-modifying anti-rheumatic drugs $[52,53]$. Bee venom shows protective and anti-inflammatory properties [54]. Normally, wearing of protective clothing reduce the risk of venomous stings, inflammation and pain (table 3). Polybia-MP1 (IDWKKLLDAAKQIL-NH2) is a lytic peptide from the Brazilian Wasp venom with known anti-cancer properties [55]. The venoms of bees, wasps, hornet, spiders, and scorpions possess pharmacologically active molecules which show anti-tumor and anti-cancer activity [56, 57] (table 3; fig. 3).

Melittin inhibits tumor cell growth and induces apoptosis. It could be used as a potential alternative or complementary medicine for the treatment of human cancers [58]. It acts as a natural detergent with the capacity to form, tetramer aggregates on membranes, which lead to disorders in the structure of phospholipid bilayers, changes in membrane potential, aggregation of membrane proteins, as well as the induction of hormone secretion [59]. Furthermore, this membrane disruption directly or indirectly leads to alterations in enzymatic systems, such as G-protein [60], protein kinase [61], adenylcyclase [62] and phospholipase [63]. Melittin can even inhibit calmodulin, a calcium-binding protein that plays a crucial role in cell proliferation [64]. Tumorous cells expose anionic phospholipids, mainly Phosphatidylserine, on the external leaflet of the plasma membrane [65]. Melittin displays anti-proliferative activity [66] and inhibit angiogenesis at cancerous sites [67]. Melittin-based recombinant immunotoxins prepared after fusion of genes that encoded an antibody fragment derived from the murine monoclonal Antibody K121 found effective in vitro [68]. Recombinant immunotoxin of melting Fused to an anti-asialo glycoprotein receptor (ASGPR) a single-chain variable fragment antibody (CA) shows anti-invasive activity in hepatocellular carcinoma cells [69]. More specifically, CTLA-4-targeted scFv-melting fusion protein acts as a potential immunosuppressive agent showed selective cytotoxicity assist in organ transplants [70]. Melittin coupled to avidin, when released induces immediate cell lysis [71] and stop cancer cell latency [72] (table 3; fig. 3).

\section{Anti-parasitic activity}

Insects possess anti-parasitic peptides, which show the much wider application in drug therapy. Both host insects and general arthropods, which live in association and co-exist with parasites, secrete anti-parasitic compounds. These compounds are used as an alternative medicine for the treatment of protozoa-related diseases, mainly caused by endemic parasites i.e. Leishmania sp., Plasmodium sp., and Trypanosomes [73]. AMPs isolated from crude animal venoms/secretions from bee/wasp venoms showed potential to treat protozoan-borne diseases [74] and become a new class of antimalarial drugs. These antimicrobial peptides (AMP) derived from insect venom have multiple therapeutic use. Bee venom AMPs (anoplin, duramycin, mastoparan X, melting, TP10 and Vida3) specifically target sporogonic stages of Plasmodium for toxicity against a mosquito cell line and $P$. bergheiookinetes [75]. More exceptionally anoplin and mastoparanX, were found toxic in an Anopheles gambiae cell line at a concentration of $25 \mu \mathrm{M}$. Most AMPs affect membrane integrity and produce lethal pores in microorganisms, including protozoan pathogens, whereas others act on internal targets or by modulation of the host immune system.

These antimicrobial peptides successfully kill malaria parasites, Plasmodium spp., in their blood or mosquito stages, or both [76]. Venom Peptides from parasitoid wasps show strong anti-parasitic potential [77]. Venom components of Asobara japonica impair cellular immune responses of host Drosophila melanogaster. The endoparasitoid female wasp Asobara japonica naturally injects toxins that kill Drosophila larvae and Insecticidal venom is neutralized [78, 79] (table 3; fig. 3). 


\section{Antimicrobial activity}

Antimicrobial peptides (AMPs) have been widely studied as an alternative to conventional antibiotics, especially for the treatment of drug-resistant infections [80]. Melittin shows strong antimicrobial properties due to its hemolytic nature. This venom peptide involves interactions with the lipid groups of the membrane [81, 82] and forms pores in the membrane and operate from various cellular actions such as orientation and aggregation states [83]. A hybrid undecapeptide derived from the well-known cecropin A and melittin showed antifungal and antibacterial activities. It also displays low cytotoxicity [84] similar to retro and retro-enantio analogs [85]. It also acts as an antibiotic and anti-malarial agent [86]. Despite the therapeutic efficacy of antimicrobial peptides, they show poor bioavailability in vivo caused by instability, cytotoxicity and hydrophobicity [87]. Antimicrobial peptides are also applied for fighting economically important plant pathogens [88]. In this category linear undecapeptides derived from cecropin-Melittin hybrids have been tested against phytopathogenic bacteria [89]. A peptide BP76 is also used for phytosanitary compositions [90]. Novartis has patented a method to produce contact lenses with an antimicrobial metal-containing layer-by-layer (LbL). In its Label design, at least one layer has a negatively charged polyphonic material, having-COO-Ag groups or silver nanoparticles. Melittin and its analogs display antiviral activities that are caused due to the selective reduction of the biosynthesis of some viral proteins. It is reported for the Melittin analog Hecate on herpes virus-1 [91] and strong melittin action on HIV-1-infected lymphoma cells [92]. Previously melittin was present to provide improved composition complementary to azidothymidine (AZT) to inhibit the reverse transcriptase and growth of HIV-infected cells [93]. Melittin is also carried in a nanoparticle construct designed to be used as a topical vaginal virucide [94]. More specially, cationic antimicrobial peptide anoplin are lipophilic in show hemolytic activity and proteolytic stability [95]. AMPs from insect venom are antimicrobial"weapons" are promising antimicrobial Agents [96]. MP-V1 from the Venom of Social Wasp Vespula vulgaris displays much higher antimicrobial activity [97] (table 3; fig. 3).

Phospholipase A1 (vPLA1) from the black-bellied hornet (Vespa basalis) catalyzes the hydrolysis of emulsified phospholipids and shows potent hemolytic activity that is responsible for its lethal effect (table 3). AMPs from insects could be used as peptide antibiotics [98]. These could be used one kind of ideal alternatives of Synthetic pesticides and the development of novel antimicrobials. Nine different AMPs were isolated from the venom gland of the wasp Vespa tropica. These AMPs have been classified into two different families based on sequence similarity, mastoparan and vespid chemotactic peptides (VCPs), and named as mastoparan-VT1 to-VT7, VCP-VT1 and-VT2 [99]. Among these nine AMPs, mastoparan-VT1 and VCP-VT1 are identical to peptides from other wasps. These nine AMPs, mastoparan-VT1 and VCP-VT1 are identical to peptides from other wasps. These AMPs exerted broad-spectrum antimicrobial activity [100] (table 3; fig. 3).

\section{Antiviral activity}

The venoms of bees and wasps are complex mixtures of biologically active proteins and peptides, such as phospholipases, hyaluronidase, phosphatase, $\beta$-glucosidase, serotonin, histamine, dopamine and nor-adrenaline [101]. Bee venom and its components, i.e. melting (MLT), phospholipase A2 (PLA2), and albumin showed inhibitory effects against viruses, i.e. Influenza A virus (PR8), Vesicular Stomatitis Virus (VSV), Respiratory Syncytial Virus (RSV), and Herpes Simplex Virus (HSV) in vitro and in vivo [102]. Bee venom toxin peptide mastoparans and its derivatives show broadspectrum antiviral activity against enveloped viruses [103]. More especially, mastoparan-derived peptide MP7-NH2 could inactivate viruses of multiple types and activate cell-mediated antiviral immune responses. Moreover, melittin a venom-derived peptide isolated from European honey bee Apis mellifera show anti-viral activity against human immunodeficiency virus (HIV) [104, 105]. It also demonstrates anti-cancer, anti-inflammatory, anti-diabetic, anti-infective, and adjuvant properties. Melittin also curbs infectivity of a diverse array of viruses, including coxsackie virus, enterovirus, influenza A viruses, human immunodeficiency virus (HIV), herpes simplex virus (HSV), Junín virus (JV), respiratory syncytial virus (RSV) Vesicular stomatitis virus (VSV), and tobacco mosaic virus (TMV). This peptide-based therapeutics are found effective against Human immunodeficiency virus (HIV), Influenza virus and Hepatitis virus B and C [106] (table 3; fig. 3).

\section{Proteolytic activity}

Trophallactic fluid secreted from larvae of wasps (subfamilyvespinae) possesses multi-cellular organisms. Larvae exhibit the capacity to fully digest and metabolize proteins [107] (fig. 1).

\section{Analgesic activity}

Normally opioid drugs are used as analgesics for sequential treatment of pain. Mastoparan Agelaia-MP I abundant class of peptides found in wasp venom. These show dose-dependent antinociceptive activity in mice. Agile-MP I induced partial and reversible blockade of the amplitude of action potential, probably interacting with voltage-gated sodium channels. It shows a significant potential impact on the central nervous system (CNS) [108]. Both melittin and albumin showed the anti-nociceptive effect to degenerative diseases of the nervous system. Venom enzymes and peptides show natural stability as an injectable solute, they also possess ability to synergize their actions by enhancing cell-cell interactions [109] (fig. 2).

\section{Anti-diabetic}

Diabetes is a metabolic disorder characterized by hyperglycemia resulting from perturbations in insulin secretion, insulin action or both. Diabetes, type 2 results in highest mortality rate worldwide. It occurs due to abnormal insulin secretion and patients display a state of impaired glucose tolerance to frank type 2 diabetes [110, 111]. For treatment of this storage disease/disorder insulin release mechanism is applied by injecting toxins isolated from animal venoms [112]. Venom toxin peptides induce electrical activity of the ion channels present in pancreatic $\beta$ cells that are involved in the insulin secretion process. These interact and modulate the electrical activity of pancreas cells. It interacts and induces molecular, cellular and physiological mechanisms of insulin granule biogenesis. This initiates with the synthesis of pre-proinsulin in the rough endoplasmic reticulum and the conversion of pre-proinsulin to proinsulin. Proinsulin begins to be packaged in the Trans-Golgi Network and is sorted into immature secretory granules. These immature granules become acidic via ATP-dependent proton pump and proinsulin undergoes proteolytic cleavage that results in formation of insulin and C-peptide. During the granule maturation process, insulin is crystallized with zinc and calcium in the form of dense-core granules. It stops degradative pathways of insulin secretion and dense-core insulin granule synthesis in affected cells [113]. Apis mellifera bee tea showed anti-hyperglycemic and antidiabetic activity [114] (table 3; fig. 3). Similarly, Iranian Honeybee (Apis mellifera) venom affect blood glucose and insulin in diabetic rats [115].

\section{Antiseptic activity}

Bracon hebetor, an ectoparasitoid showed dose-dependent abrogation of nitric oxide (NO) production. It suppresses the levels of proinflammatory mediators and cytokines without posing any cytotoxicity via the nuclear factor kappa B (NF-kB) and mitogenactivated protein [116]. Insect venom toxins show very strong action against human pathogens, which could act as anti-septic agents (table 3). Insect venom toxins are biologically active natural products [117] which could become a natural source of analgesics [118] (fig. 2).

\section{Anti-oxidative activity}

Bee Venom suppresses high fat diet-induced obesity by inhibiting adipogenesis. It enhances fat desorption [119]. Mastoparan-B is a toxin peptide isolated from the venom of Vespa basalis the most dangerous hornet found in Taiwan. MP-B, influences of mast cell degranulation and hemolytic activities (table 3). It acts as an antioxidant at low concentration in competing with nitricoxide oxygen molecules and possesses good anti-oxidative enzyme 
activities resembled to superoxide dismutase and glutathione peroxidase [120] (fig. 2).

\section{Cytogenotoxic effects}

The venoms of wasps are a complex mixture of biologically active low molecular mass compounds, peptides, and proteins (table 3). Venoms of Polybia occidentalis and Polybia fastidious act on the human leukocytes DNA and inhibit cell cycle. It severely affect constitution of genetic material in plant model Lactuca sativa $L$. (lettuce) [121] (fig. 2).

\section{Insecticidal activity}

Hymenoptera insects possess complex mixtures of toxins in its venoms which are used for self-defense, to repel intruders and to capture prey. These selectively target receptors found on brain cells of insects and stop insect movements. These could be used as good source for new insecticidal compounds for making new, highly potent drugs. Several insecticidal peptides or polyamine-like compounds have been purified and characterized from the venom of arachnids and hymenopterans [122]. These are used as bioinsecticides for insect control [123]. Venom toxin peptides show catalytic activity and form pores in biological membranes [124]. Peptides isolated from the venom of social Wasp Charter gellus communis (Hymenoptera: Vespidae) show hyperalgesic, edematogenic and hemolytic effects. Wasp origin peptides and proteinaceous toxins target voltage-gated sodium ( $\mathrm{NaV}$ ) channels could be used as pharmacological tools $[125,126]$. Toxin-based bioactive drugs are mainly prescribed [127] for anaphylaxis and fatal sting management $[128,129]$. It is also used in clinical treatments for $V$. velutina induced toxic reactions and allergic effects [130]. Hymenoptera venom allergens are also used for the rational design of component-resolved diagnosis of allergy, mainly for improving the outcome of venom immunotherapy (VIT) [131] (table 3, fig. 3).

\section{Therapeutic uses}

Melittin, hyaluronidase and PLA2 are the main component of bee venom which impose allergic reactions in man [132]. Melittin is an amphiphilic peptide comprising 26 amino acid residues, its aminoterminal region is predominantly hydrophobic and, the carboxylterminal region is hydrophilic. Melittin is the principal active component of apitoxin and is responsible for breaking up and killing cells. When several melittin peptides accumulate in the cell membrane, phospholipid packing is severely disrupted, thus it leading to cell lysis $[133,134]$ fig. 3). Melittin triggers not only the loss of a wide range of plasmatic membranes, but also of intracellular ones such as those found in mitochondria. PLA2 and melittin act synergistically, breaking up membranes of susceptible cells and enhancing their cytotoxic effect [135] Melittin induced cell damage, in turn, may lead to the release of other harmful compounds, such as lysosomal enzymes from leukocytes, serotonin from thrombocytes, and histamine from mast cells, which can all lead to pain ((table 3; fig. 3). Melittin is the most known bee venom peptide that is widely used in so many clinical applications. It acts as an immunologic adjuvant and therapies used for the treatment of rheumatoid arthritis, arteriosclerosis, cancer, and endosomolytic properties for drug delivery. It strongly acts like as an antibiotic and help to finish microbial infections. It is also used in antiretroviral therapy to reduce the passage of HIV-1 and to limit the viral load in infected people [136]. Both Melittin and its analogs are capable of eliciting strong immune responses against viral antigens. These reduce the risk of toxic side effects associated with the use of adjuvant [137]. Macrophages secrete pro-inflammatory cytokines, a main cellular component in the development of atherosclerotic plaques [138]. It dissolves atherosclerotic plaques formed in blood vessels and is used for the treatment of atherosclerosis [139, 140]. This molecular mechanism of the anti-atherosclerotic effects of melittin is established in mice models [141] (table 3; fig. 3).

Albumin is a peptide neurotoxin comprising 18 amino acid residues that tightly cross-linked by the presence of two disulphide bonds [142]. It shows many hyperpolarising-inhibitory effects, including alpha-adrenergic, cholinergic, purinergic, and neurotensin-induced relaxations [143]. Unlike melittin, apamin is a peptide with a highly specific mode of Action. It binds and occludes the pore of small conductance Ca2+-triggered $\mathrm{K}+$ channels (SK), thus acting as an allosteric inhibitor [144] and depressing delayed cell hyperpolarization. This binding specificity of albumin and its electrical properties could be exploited in biomedical research. Albumin acts mainly on the CNS, where SK channels are widely expressed [145] (fig. 3). SK channels are of three types based on their conductance and third small conductance (SK or K3) [146]. These channels are activated solely by increase in intracellular $\mathrm{Ca} 2+$ contribute to regulating the excitability and function of many cell types, including neurons, epithelial cells, T-lymphocytes, and skeletal muscle cells [147]. SK channels are activated by sub micromolar concentrations of $\mathrm{Ca} 2+$, and this activation is mediated by calmodulin [148]. In excitable cells, the activation of SK channels generates a hyperpolarizing $\mathrm{K}+$ current which contributes to the after hyperpolarisation (AHP) that follows an action potential. This AHP modulates cell firing frequency and spike frequency adaptation, thereby influencing neuronal excitability. SK channels have been implicated in diverse physiological functions such as synaptic enhancement and long 7 term potentiation. Apamin injections accelerate acquisition of the bar-pressing response and also accelerate bar-pressing rates $[149,150]$. Wasp and honey bee and hornet toxin peptides because convulsions due to presence of albumin a rigid octadecapeptide but it is no longer be considered an exclusive neurotoxin. [151]. Contrary to this apamin is show cellular toxicity in vital organs $[152,153]$ (table 3 ; fig. 3).

\section{Hymenoptera venom allergy}

Allergen immunotherapy (AIT) is used to desensitize the allergen injected by venomous insects. It successfully switches off the allergy over time and become an effective treatment for allergies to bee and wasp stings [154]. It is mostly used to stop systemic allergic sting reactions. This is also used for the treatment of chronic inflammatory disease, especially arthritis. Hymenoptera venom proteins and peptides are used for Diagnosis and treatment of venom allergic patients [155]. In allergen immunotherapy, hypo sensitization are considered for therapeutic purposes by changing the dose level. The effect depends to some degree on the original intensity of hypersensitivity [156]. Hypersensitivity is mostly developed in beekeepers because of frequent exposure of honey-bee stings. This long-term exposure to venom toxins induces immune tolerance in them. This is the main reason that the prevalence of systemic reactions to bee stings in beekeepers is very low (approximately $14 \%$ to $42 \%$ ) while very high immune tolerance $(67-90 \%)$ is observed due to continued exposure of toxins. All it happens after adaptive immune responses in them [157] (table 3; fig. 3).

\section{Apitherapeutics}

Apitherapy is an alternative therapy in which honey bee products are directly used against honey bees. Apitherapy is used to treat multiple sclerosis, arthritis, infections, and shingles. It is used to treat illnesses wounds, burns, tendonitis as well as pain and acute and chronic injuries. In Apitherapy, honeybee products are applied topically, or intake orally, or provided injection. Apitherapists promote the medical use of products from the beehive (bee venom, propolis, pollen, honey, royal jelly and dead bees. It is also a fact that the majority of patients show un-willingness to apitherapy because they feel that they cannot tolerate such treatments. Therefore, therapeutic modifications are needed for increasing acceptability [158] (table 3; fig. 3). It is true that significant numbers of modern-day pharmaceuticals are derived from natural products, mainly venoms of various origins show therapeutic potentials. In the present time due to the increasing rate of drug resistance of the pathogen organisms and target cells as well as the dependence or tolerance of the body towards the drug, venom toxins are seen novel candidates for making pharmaceutical agents. Wasp venoms are also a rich source of therapeutically important toxins, which includes short cationic peptides, kinins, polyamines and poly DNA viruses. These have diverse therapeutic significance.

\section{Mode of action}

Insect toxins comprise a diverse array of chemicals ranging from small molecules, polyamines and peptide toxins. Many target nervous systems and neuromuscular ion channels and so rapidly 
affect the behavior of animals to which the toxin is applied or injected. Other modes of action have also been identified. Wasps, bees, flies, and ants generate a rich arsenal of channel-active toxins, some of which offer selective pharmacological probes that target particular ion channels, while others act on more than one type of channel. Philanthotoxins from the digger wasp target ligandgated ion channels, both in the nervous system and at neuromuscular junctions. Apamin from bee venom targets calciumactivated potassium channels, which can in turn influence their lease of neuropeptides. Melittin acts on the membrane surface. Mastoparan is a powerful peptide toxin present in the venom of wasps. Its toxic actions can be engineered out, leaving a potent antimicrobial molecule of interest. Hymenopteran wasps contain albumin that interacts neuronal receptors and play an important role in prey paralysis in small insects [159]. This interaction may play a crucial role in most of the cellular process; formation of complexes, binding specificity could be utilized for the design molecules [160]. The crude honey bee (Apis mellifera) venom also acts on the skeletal, smooth as well as cardiac muscles. It also shows neurotoxicity of inhibitory nature involving the autonomic as well as neuromuscular system [160]. This secretory phospholipases A2 (sPLA2s) have specific receptors in brain membranes called N-type receptors. It binds to the $\mathrm{N}$ receptor recognition domain of the toxin. Neo nicotinoids are agonists of nicotinic acetylcholine receptors; they disturb acetylcholine receptor signaling leading to neurotoxicity. The main element which imposes this neurotoxicity is Phospholipase A2 that displays $\mathrm{N}$-type receptor binding. Bee venom toxins also bind to to cell surface receptors, ion channels and ion gated channels or by passive diffusion by making pinholes in cellular parasites [161](fig. 3). Honey bee venom, shows induction of apoptosis in malignant cells [162]. It shows the inhibitory, anti- invasive and cytotoxic effect on several types of cancer lines [163]. Bee venom components melittin shows showed anti-proliferative and anti-metastatic properties and apoptosis in malignant glioma cells [164, 165] (fig. 3). These stops progression of cancer and inhibit metastasis in cancer cell lines [166]. Besides this, honeybees prepare a sticky substance (called propolis/bee glue) by mixing saliva poplar tree resin; this natural product shows therapeutic benefits against breast cancer. Milestone is also used as a Promising Adjuvant treatment for brain tumors [167-169]. Till date so many major toxins/allergens have been identified in many species of wasps and bees, which are of very high medical importance $[170,171]$. These toxins have been characterized for their biological activity and their differential gene profiling has been done $[172,173]$. There is need of molecular docking important data on toxins for development of effective therapeutics through A combination of transcriptomic, proteomic, peptidomic, glycemic and venomic approaches [174, 175] (fig. 3). More often, the data available in various databases on peptide toxins can be used for comparative transcriptome analysis of the venom sac and gland of several species [176-178]. It will assist in identifying its confirmatory biological activity in animal models $[179,180]$. These toxin peptides can be used to develop new diagnostic and therapeutic approaches for the treatment of poisonous animal stings and bites [181]. Production of anti-venom serum against important toxins and allergens can be used in immunotherapy to encounter envenomation (table 3; fig. 3). Severe allergies or allergies may not be completely relieved by other treatments; hence, allergen immunotherapy can be applied. It involves a series of injections of purified allergen extracts, usually given over a period of a few years. No doubt hornet, honey bee and wasp venoms are of therapeutic and biotechnological use.

Table 1: Toxins found in wasp venom allergens and their molecular weight and biological effects

\begin{tabular}{|c|c|c|c|c|}
\hline Species & Toxin & Mw & Biological effects & Source \\
\hline Vespa, protopolybia & Kinnin and polyamines & 32,000 & Cytotoxic, anticancer & 24 \\
\hline Vespa flavitarsus & Hornetin & 32,000 & Antimicrobial, anticancer, neurotoxicity & 25 \\
\hline Vespa vulagaris & Hyluronidase A & 43000 & Cytotoxic & 98 \\
\hline Polibia polista & Cationicpepetides (Polibia MP-1) & 1611.98 & Antifungal & 120 \\
\hline Bees & Phospholipase $\mathrm{A}_{2}$ & $\begin{array}{l}16000 \\
14500(-\mathrm{CHO})\end{array}$ & Hydrolysis of lecithins & 174 \\
\hline Bees, wasps & Hyaluronidase & 33000 & Allergenic activity & 174 \\
\hline Bees & Acid phosphatase & 48000 (monomer) & $\begin{array}{l}\text { Inflammation, coagulation factor, apoptosis } \\
\text { of ovarian cells, antimicrobial activity }\end{array}$ & 174 \\
\hline Honeybees & Melittin & 11360 (tetramer) & cytotoxic effect & 174 \\
\hline Bumblebees & Tryptic amidase & 27250 & Proteolytic activity & 174 \\
\hline Wasps, ants & Phospholipase $\mathrm{A}_{1} \mathrm{~B}$ & 33500 & Allergenic activity & 174 \\
\hline Wasps, ants & Antigen 5 & 23000 & Pain, allergenic activity & 174 \\
\hline Fire ants & Sol 2 & 26432 (dimer) & Antimicrobial activity & 174 \\
\hline Fire ants & Sol i 4 & 13340 & Antimicrobial activity & 174 \\
\hline Jack-jumper and bulldog ants & Myr p 1 & 9103 (precursor) & Antimicrobial activity & 174 \\
\hline Jack-jumper and bulldog ants & Myr p 2 & 8144 (precursor) & Antimicrobial activity & 174 \\
\hline
\end{tabular}

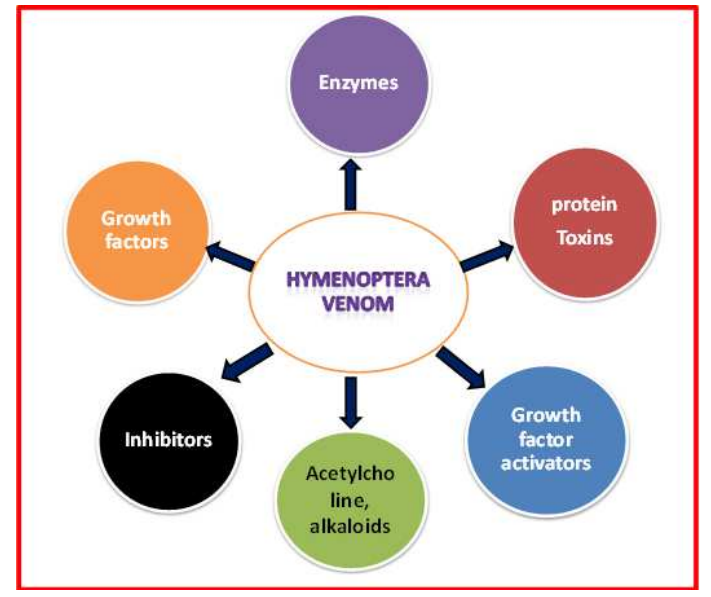

Fig. 1: Hymenopteran venom toxins and its constituent molecules 
Table 2: Showing major hymenopteran insect venom derived toxins/allergen with their major biological activity

\begin{tabular}{|c|c|c|c|c|c|}
\hline S. No. & Species name & Common name & Allergen type & Biological activity & Source \\
\hline 1. & $\begin{array}{l}\text { Vespa } \\
\text { mandarinia }\end{array}$ & Asian giant hornet & Allergen5, chemotactic peptide & $\begin{array}{l}\text { Inflammatory activity, antimicrobial } \\
\text { activity, causes allergic reaction in human }\end{array}$ & 1 \\
\hline 2. & Vespa velutina & $\begin{array}{l}\text { Asian predatory } \\
\text { wasp }\end{array}$ & $\begin{array}{l}\text { Agatoxinlike, analgesic polypeptide, } \\
\text { oriento toxin like peptide }\end{array}$ & $\begin{array}{l}\text { Hemolytic activity, paralysis (calcium } \\
\text { channel blocking), }\end{array}$ & 5 \\
\hline 4. & Vespa bicolor & Black shield wasp & Mastoparan & $\begin{array}{l}\text { Allergic inflammation (mast cell } \\
\text { degranulation) }\end{array}$ & 5 \\
\hline 5. & Vespa crabo, & European hornet & $\begin{array}{l}\text { Calsyntenin, leucine-rich repeat } \\
\text { domain containing protein }\end{array}$ & $\begin{array}{l}\text { Paralysis (calcium channel blocking), } \\
\text { antimicrobial activity }\end{array}$ & 5 \\
\hline 6. & $\begin{array}{l}\text { Vespa } \\
\text { xanthoptera }\end{array}$ & $\begin{array}{l}\text { Japanese yellow } \\
\text { hornet }\end{array}$ & chemotactic peptide & Inflammatory activity, antimicrobial activity & 5 \\
\hline 7. & Vespa affinis & $\begin{array}{l}\text { Lesser banded } \\
\text { hornet }\end{array}$ & Phospholipase A1 & Production of lipid mediator & 6 \\
\hline 8. & $\begin{array}{l}\text { Vespa } \\
\text { germanica }\end{array}$ & $\begin{array}{l}\text { German or } \\
\text { European wasp }\end{array}$ & Allergen 5 & Allergenic activity & 7 \\
\hline 9. & Agelia pallipes & Agalia & Wasp chemotactic peptide & $\begin{array}{l}\text { Allergenic inflammation } \\
\text { Antimicrobial activity, mast cell } \\
\text { degranulation }\end{array}$ & 7 \\
\hline 10. & Agelia vicina & & $\mathrm{AV}, \mathrm{Tx} 7,8$ & Paralysis ( $\mathrm{K}^{+}$channel blocking) & 7 \\
\hline 11. & $\begin{array}{l}\text { Dolicho vespula } \\
\text { maculate }\end{array}$ & Yellowjackets & Allergen 5 & Allergenic activity & 7 \\
\hline 12. & Vespa orientalis & Oriental hornet & Oriento toxin like peptide & $\begin{array}{l}\text { Paralysis (pre-synaptic effect, } \\
\text { lysophospholipase activity }\end{array}$ & 19 \\
\hline 13. & $\begin{array}{l}\text { Protopolibia } \\
\text { exigua }\end{array}$ & $\begin{array}{l}\text { Neotropical social } \\
\text { wasp }\end{array}$ & Mastopran & $\begin{array}{l}\text { Allergic inflammation, mast cell } \\
\text { degranulation }\end{array}$ & 24 \\
\hline 14. & $\begin{array}{l}\text { Polistes } \\
\text { infuscatus }\end{array}$ & $\begin{array}{l}\text { Golden or } \\
\text { northern paper } \\
\text { wasp }\end{array}$ & Allergen5, wasp kinin & Pain, allergenic activity & 19 \\
\hline 15 & $\begin{array}{l}\text { Polistes } \\
\text { infuscatus }\end{array}$ & Paper wasp & Wasp kinin,mastoparan & $\begin{array}{l}\text { Pain production, allergic inflammation(mast } \\
\text { cell degranulation) }\end{array}$ & 19 \\
\hline 16 & $\begin{array}{l}\text { Polistes } \\
\text { jadwiqae }\end{array}$ & Paper wasp & Wasp kinin,mastoparan & $\begin{array}{l}\text { Pain production, allergic inflammation(mast } \\
\text { cell degranulation) }\end{array}$ & 19 \\
\hline 17. & $\begin{array}{l}\text { Paravespula } \\
\text { lewisii }\end{array}$ & Yellowjackets & Wasp chemotactic peptide & Inflammatory activity, antimicrobial activity & 19 \\
\hline 18. & $\begin{array}{l}\text { Paravespula } \\
\text { maculifrons }\end{array}$ & $\begin{array}{l}\text { Western yellow } \\
\text { jackets }\end{array}$ & Wasp kinin & Pain production & 19 \\
\hline 19. & $\begin{array}{l}\text { Protonectarina } \\
\text { sylveira }\end{array}$ & Brazilian wasp & Wasp chemotactic peptide & Inflammatory activity, antimicrobial activity & 48 \\
\hline 20. & $\begin{array}{l}\text { Polistes } \\
\text { exclamans }\end{array}$ & Paper wasp & Wasp kinin, allergen 5 & Pain production, allergenic activity & 89 \\
\hline 21. & Vespa tropica & Oriental hornet & Wasp kinin, mastoparan & $\begin{array}{l}\text { Pain production, Allergic inflammation } \\
\text { (mast cell degranulation) }\end{array}$ & 99 \\
\hline 22. & Polistes major & Paper wasp & Wasp kinin & Pain production & 90 \\
\hline 32. & Vespa basalis & $\begin{array}{l}\text { Black-bellied } \\
\text { hornet }\end{array}$ & Dipeptidyl peptidase IV & Metabolism of organic compound & 120 \\
\hline 23. & Ropalidia & Yellow jackets & Mastoparan & $\begin{array}{l}\text { Allergenic inflammation(mast cell de- } \\
\text { granulation) }\end{array}$ & 170,171 \\
\hline 24. & $\begin{array}{l}\text { Vespa } \\
\text { xanthoptera }\end{array}$ & $\begin{array}{l}\text { Japanese yellow } \\
\text { hornet }\end{array}$ & Wasp kinin, Mastoparan & $\begin{array}{l}\text { Pain production, allergenic } \\
\text { inflammation(mast cell degranulation) }\end{array}$ & 170,171 \\
\hline 25. & Vespa analis & $\begin{array}{l}\text { Yellow-vented } \\
\text { hornet }\end{array}$ & $\begin{array}{l}\text { Leucine-rich repeat domain } \\
\text { containing protein, wasp kinin, } \\
\text { mastopran, acetylcholinesterases, }\end{array}$ & $\begin{array}{l}\text { Paralysis, pain, allergic, hemolytic factor, } \\
\text { inflammatory response, synaptic } \\
\text { organization, coagulation factor }\end{array}$ & 170,171 \\
\hline 26 & Vespa ducalis & & Mastoparan & $\begin{array}{l}\text { Allergic inflammation (mast cell } \\
\text { degranulation }\end{array}$ & 170,171 \\
\hline 27. & $\begin{array}{l}\text { Vespa } \\
\text { flavopilosa }\end{array}$ & Red wasp & Allergen 5 & Allergenic activity & 170,171 \\
\hline 28. & Vespula lewisii & Italian wasp & Mastoparan & $\begin{array}{l}\text { Allergic inflammation (mast cell } \\
\text { degranulation }\end{array}$ & 170,171 \\
\hline 29. & $\begin{array}{l}\text { Vespula } \\
\text { pensylvanica }\end{array}$ & $\begin{array}{l}\text { Western yellow } \\
\text { jacket }\end{array}$ & Allergen 5 & Allergenic activity & 170,171 \\
\hline 30. & $\begin{array}{l}\text { Vespula } \\
\text { squamosa }\end{array}$ & $\begin{array}{l}\text { Southern yellow } \\
\text { jacket }\end{array}$ & Allergen 5 & Allergenic activity & 170,171 \\
\hline 31. & Vespula vidua & $\begin{array}{l}\text { Long yellow jacket } \\
\text { or widow yellow } \\
\text { jacket }\end{array}$ & Allergen 5 & Allergenic activity & 170,171 \\
\hline
\end{tabular}


Table 3: Toxin peptides found in various species of wasp, bee and hornet with its biological activities

\begin{tabular}{|c|c|c|c|}
\hline Species & Peptides & Biological activities & References \\
\hline Eumenes pomiformis & Dendrotoxin-like & Paralysis ( $\mathrm{K}^{+}$channel blocking) & 175,177 \\
\hline Anterhynechium flavomarginatum & Mastoparan-like & Allergic inflammation Antimicrobial activity & 175,177 \\
\hline Cyphononyx fulvognathus & Wasp chemotactic peptide & Inflammatory activity Antimicrobial activity & 175,177 \\
\hline Orancistro cerus drewseni & Tyrosine 3-monooxygenase & Regulation of dopamine synthesis & 175,177 \\
\hline $\begin{array}{l}\text { Orancistro cerus drewseni Rhynchium } \\
\text { brunneum }\end{array}$ & Actin & $\begin{array}{l}\text { Regulation of hemocyte cytoskeleton gene } \\
\text { expression }\end{array}$ & 175 \\
\hline Orancistrocerus dresweri & Arginine kinase & Paralysis & 175 \\
\hline Rhynchiumbrunneum & ATP synthase & ATP synthesis & 176,177 \\
\hline Eumenes pomiformis & Alcohol dehydrogenase & Oxidation of ethanol to acetaldehyde & 177 \\
\hline Eumene spomiformis & Glutamate decarboxylase & $\begin{array}{l}\text { Involvement in beta-cell-specific } \\
\text { autoimmunity }\end{array}$ & 177 \\
\hline Eumenespomiformis & $\begin{array}{l}\text { Insulin-like peptide-binding } \\
\text { protein }\end{array}$ & $\begin{array}{l}\text { Developmental arrest (Inhibition of insulin } \\
\text { signaling) }\end{array}$ & 177 \\
\hline Eumene spomiformis & HECT E3 ubiquitin ligase & Regulation of cell trafficking & 177 \\
\hline Eumene spomiformis & Hyaluronidase & Venom dissemination & 177,178 \\
\hline Rhynchium brunneum & $\begin{array}{l}\text { Farnesoic acid } O \text { - } \\
\text { methyltransferase }\end{array}$ & $\begin{array}{l}\text { Regulation of biosynthetic pathway of juvenile } \\
\text { hormone }\end{array}$ & 178 \\
\hline Rhynchium brunneum & Acetyl-CoA synthase & Involvement in metabolism of acetate & 178 \\
\hline Rhynchium brunneum & Amidophosphoribosyltransferase & Regulation of cell growth & 178 \\
\hline Rhynchium brunneum & Cytochrome P450 monooxygenase & Metabolism of toxic compounds & 178 \\
\hline Rhynchium brunneum & Carboxylesterase & Lipid metabolism & 178 \\
\hline Rhynchium brunneum & Citrate synthase & Catalyzing the citric acid cycle & 178 \\
\hline Rhynchium brunneum & DNA-directed RNA polymerase & Synthesis of mRNA precursor & 178 \\
\hline Rhynchium brunneum & $\begin{array}{l}\text { Glyceraldehyde-3-phosphate } \\
\text { dehydrogenase }\end{array}$ & Direct hemolytic factor & 178 \\
\hline Rhynchium brunneum & Glycogenin & Synthesis of glycogen & 178 \\
\hline Rhynchium brunneum & Myo inositol monophosphatase & Regulation of inositol homeostasis & 178 \\
\hline Rhynchium brunneum & Phospholipase A2 & Hydolysis of lecithins & 177,178 \\
\hline \multicolumn{4}{|l|}{ Eumenespomiformis } \\
\hline Rhynchium brunneum & Protein tyrosin phosphatase & Regulation of cellular processes & 178 \\
\hline Rhynchium brunneum & $\begin{array}{l}\text { Serine/threonine-protein } \\
\text { phosphatase }\end{array}$ & Regulation of biochemical pathways & 178 \\
\hline Orancistro cerus drewseni & Metalloendopeptidase & Inhibition of platelet aggregation & 177,178 \\
\hline Rhynchium brunneum & Neprilysin & Inhibition of platelet aggregation & 178 \\
\hline Rhynchium brunneum & Ankyrin & $\begin{array}{l}\text { Attachment of membrane proteins to } \\
\text { membrane cytoskeleton }\end{array}$ & 178 \\
\hline $\begin{array}{l}\text { Orancistro cerus drewseni Rhynchium } \\
\text { brunneum }\end{array}$ & Bmkettin & Development of flight muscles & 176,178 \\
\hline $\begin{array}{l}\text { Orancistro cerus drewseni Rhynchium } \\
\text { brunneum }\end{array}$ & Calponin & Regulation of myogenesis & 176,178 \\
\hline \multicolumn{4}{|l|}{ Eumenespomiformis } \\
\hline $\begin{array}{l}\text { Orancistro cerus drewseni Rhynchium } \\
\text { brunneum }\end{array}$ & Muscle LIM protein & Regulation of myogenesis & 176,178 \\
\hline \multicolumn{4}{|l|}{ Eumenespomiformis } \\
\hline $\begin{array}{l}\text { Orancistro cerus drewseni } \\
\text { Eumenes pomiformis }\end{array}$ & Muscle protein 20 Myomesin & Regulation of muscle contraction & 176,178 \\
\hline Rhynchium brunneum & Myosin heavy chain & Regulation of muscle functions & 179 \\
\hline $\begin{array}{l}\text { Orancistroceru drewseni Rhynchium } \\
\text { brunneum }\end{array}$ & Myosin light chain & Modulation of the affinity of myosin for actin & 176,178 \\
\hline \multicolumn{4}{|l|}{ Eumenes pomiformis } \\
\hline $\begin{array}{l}\text { Orancistr oceru sdrewseni Rhynchium } \\
\text { brunneum Eumenespomiformis }\end{array}$ & Paramyosin & Regulation of thick filament in muscles & 176,178 \\
\hline $\begin{array}{l}\text { Orancistrocerus drewseni Rhynchium } \\
\text { brunneum Eumenespomiformis }\end{array}$ & Titin & $\begin{array}{l}\text { Assembly of contractile machinery in muscle } \\
\text { cells }\end{array}$ & 176,178 \\
\hline $\begin{array}{l}\text { Orancistro cerus drewseni Rhynchium } \\
\text { brunneum }\end{array}$ & Tropomyosin & Muscle contraction & 176,178 \\
\hline $\begin{array}{l}\text { Orancistro cerusdrewseni Rhynchium } \\
\text { brunneum }\end{array}$ & Troponin & Muscle contraction & 176,178 \\
\hline $\begin{array}{l}\text { Orancistrocerus drewseni Rhynchium } \\
\text { brunneum Eumenespomiformis }\end{array}$ & Tubulin & $\begin{array}{l}\text { Regulation of hemocyte skeleton genes } \\
\text { expression }\end{array}$ & 176,178 \\
\hline Rhynchium brunneum & Chemosensory protein & $\begin{array}{l}\text { Transferring metabolism-related small } \\
\text { molecules }\end{array}$ & 178 \\
\hline $\begin{array}{l}\text { Orancistrocerusdrewseni Rhynchium } \\
\text { brunneum }\end{array}$ & Cytochrom C & Protein wire & 176,178 \\
\hline $\begin{array}{l}\text { Orancistro cerus drew seni Rhynchium } \\
\text { brunneum }\end{array}$ & Heat shock proteins & Prevention of protein misfolding & 175,178 \\
\hline \multicolumn{4}{|l|}{ Eumenes pomiformis } \\
\hline Rhynchium brunneum & Sialin & Nitrate transporter & 179 \\
\hline Rhynchium brunneum & Sugar transporter & Maintenance of glucose homeostasis & 179 \\
\hline Batozonellusmaculifrons & $\beta$-pompilidiotoxin & Paralysis ( $\mathrm{Na}^{+}$channel blocking) & 181 \\
\hline Anoplius samariensis & $\alpha$-pompilidiotoxin & Paralysis $\left(\mathrm{Na}^{+}\right.$channel blocking) & 181 \\
\hline
\end{tabular}




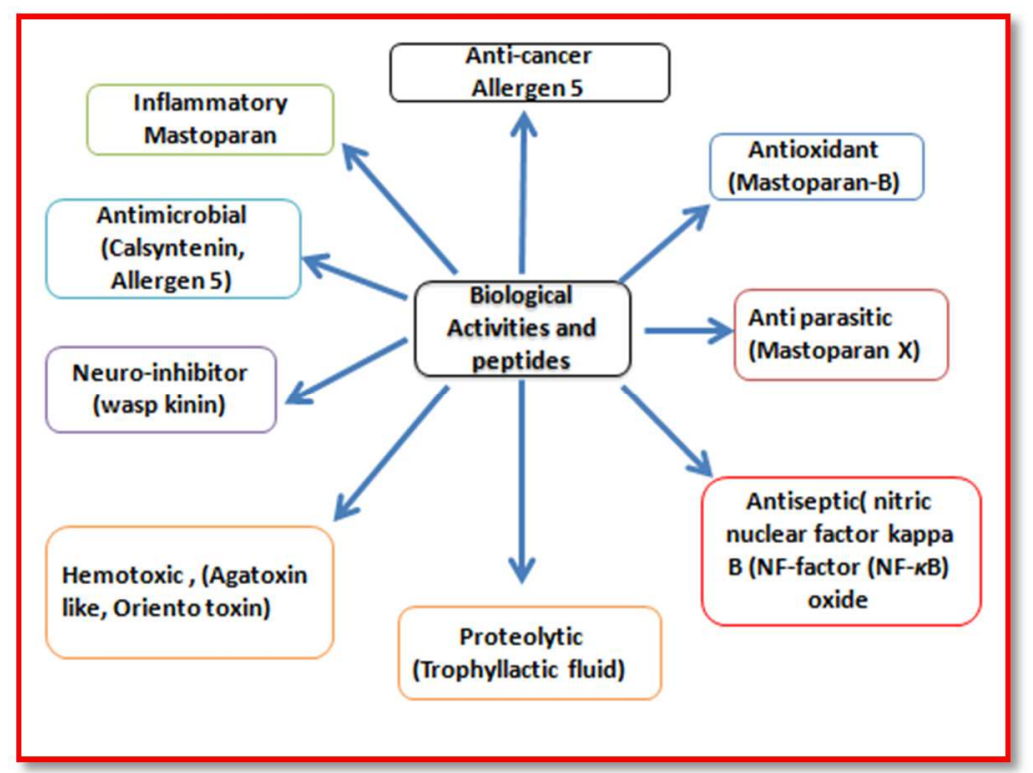

Fig. 2: Hymenopteran venom toxins and its various biological activities

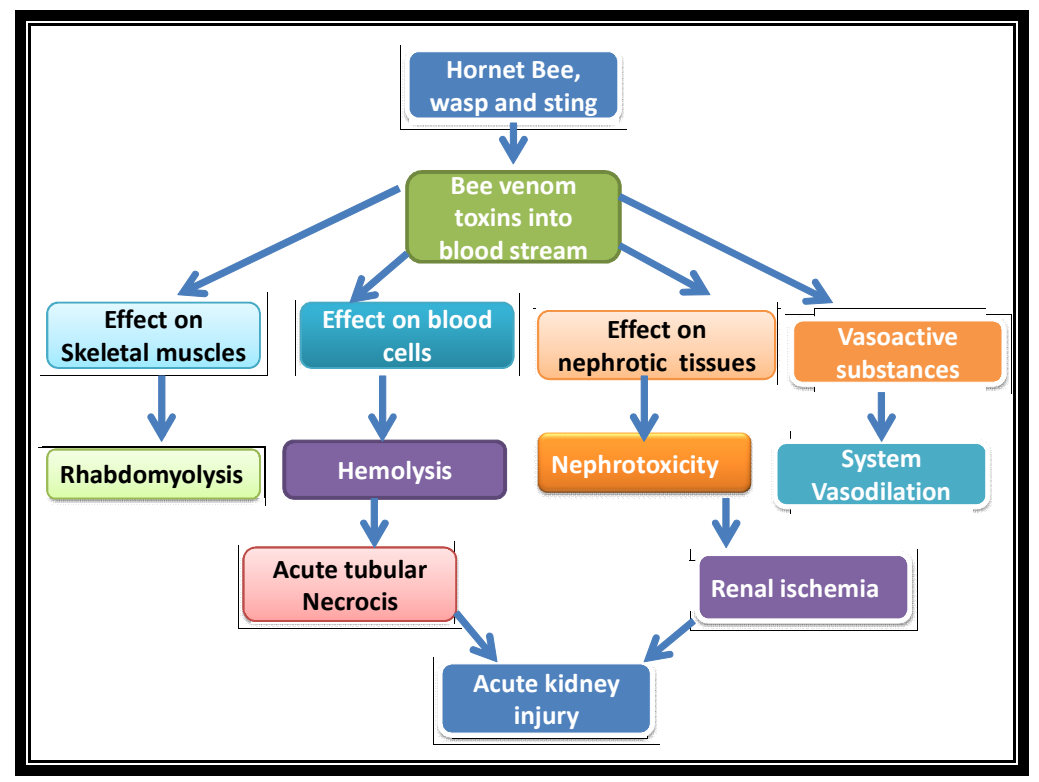

Fig. 3: Hymenopteran venom toxins and its effect on vital organ systems

\section{CONCLUSION}

Hymenoptera venom is a complex mixture of many substances such as toxins, enzymes, growth factor activators, and inhibitors. It contains few biologically important enzymes, i.e. phospholipases acid phosphatase, Proteases and therapeutically important peptides such as Mastoparan-C (MP-C), scapin A, apamin, Mast cell degranulating (MCD) peptide, Bradykinin, AMPs which display diverse therapeutic potential. Hymenopteran insect venom toxins are highly specific as they show diversity in structure and function. Insect venom is a good source of proteinaceous toxins and enzymes mainly smaller protein toxins, and non-proteinaceous molecules. These components are highly active toxic agents as they generate multiple clinical and pathophysiological changes such as severe inflammation and pain. Bee venom is also used in healing treatment for various disorders. More especially bio-molecules found in hornets, bees and wasps have shown anti-tumor and anti-cancer activity, antioxidant, anti-parasitic, antiseptic, proteolytic, catalytic, hemotoxic, neuro-inhibitor, anticancer, antimicrobial, immune hypersensitive, inflammatory, antimicrobial and anti-insect activities. Insects possess anti-parasitic peptides which show much wider application in alternate drug therapy. These compounds are used as an alternative medicine for the treatment of protozoa-related diseases, mainly caused by endemic parasites: Leishmania sp., Plasmodium sp., and Trypanosomes. Honey bee venom shows an anti-parasitic effect against Entamoeba histolytica and Giardia lamblia trophozoites in the sub-culture method due to quick transport through a membrane or their binding. Venom toxin structures are also important and there is a need to make interconnection among biochemistry, pharmacology and immunology areas for the expansion of knowledge and for the generation of innovation in the field of therapeutic and pharmaceutical research.

\section{ACKNOWLEDGEMENT}

Authors are thankful to H. O. D., Department of Zoology for research facilities.

\section{FUNDING}




\section{AUTHORS CONTRIBUTIONS}

All the authors have contributed equally.

\section{CONFLICT OF INTERESTS}

The authors declare no competing financial interests.

\section{REFERENCES}

1. Warrell DA. Venomous bites, stings, and poisoning: an update. Infect Dis Clin North Am 2019;33:17-38.

2. Archer ME. Taxonomy of the sylvestris group (Hymenoptera: Vespidae, Dolichos vespula) with the introduction of a new name and notes on distribution. Entomological Scandinavica 1981;12:187-93.

3. Dos Santos Pinto JRA, Perez Riverol A, Lasa AM, Palma MS. Diversity of peptidic and proteinaceous toxins from social hymenoptera venoms. Toxicon 2018;148:172-96.

4. Pessoa WFB, Silva LCC, De Oliveira Dias, L Delabie. CC analysis of protein composition and bioactivity of Neoponera villosa venom (Hymenoptera: Formicidae. Int J Mol Sci 2016;17:513.

5. Liu Z, Chen S, Zhou Y, Xie C, Zhu B, Zhu H, et al. Deciphering the venomictranscriptome of killer-wasp Vespa velutina. Sci Rep 2015;5:9454.

6. Kularatne K, Kannangare T, Jayasena A, Jayasekera A, Waduge R, Weerakoon K, et al. Fatal acute pulmonary oedema and acute renal failure following multiple wasp/hornet (Vespa affinis) stings in Sri Lanka: two case reports. J Med Case Rep 2014;8:188.

7. Baptista Saidemberg NB, Saidemberg DM, Palma MS. Profiling the peptidome of the venom from the social wasp Agelaia pallipes pallipes. J Proteomics 2011;74:2123-37.

8. Brigatte P, Cury Y, de Souza BM, Baptista Saidemberg NB, Saidemberg DM, Gutierrez VP, et al. Hyperalgesic and edematogenic effects of peptides isolated from the venoms of honeybee (Apis mellifera) and neotropical social wasps (Polybia paulista and Protonectarina sylveirae). Amino Acids 2011;40:101-11.

9. Diaz JH. The evolving global epidemiology, syndromic classification, management, and prevention of caterpillar envenoming. Am J Trop Med Hyg 2005;72:347-57.

10. Petricevich VL. Cytokine and nitric oxide production following severe envenomation. Curr Drug Targets Inflamm Allergy 2004;3:325-32.

11. Huicab Uribe MA, Verdel Aranda K, Martinez Hernandez A, Zamudio FZ, Jimenez Vargas JM, Lara Reyna J. Molecular composition of the paralyzing venom of three solitary wasps (Hymenoptera: Pompilidae) collected in southeast mexico. Toxicon 2019;168:98-102.

12. Alvarado G, Holland SR, DePerez-Rasmussen J, Jarvis BA, Telander $\mathrm{T}$, Wagner $\mathrm{N}$, et al. Bioinformatic analysis suggests potential mechanisms underlying parasitoid venom evolution and function. Genomics 2019;112;1096-104.

13. Elias LG, Silva DB, Silva R, Peng YQ, Yang DR, Lopes NP, et al. A comparative venomic fingerprinting approach reveals that galling and non-galling fig wasp species have different venom profiles. PLoS One 2018;13:e0207051.

14. Catania KC. How not to be turned into a zombie. Catania KC. Brain Behav Evol 2018;92:32-46.

15. Hider RC, Ragnarsson U. A comparative structural study of apamin and related bee venom peptides. Biochim Biophys Acta 1981;667:197-208.

16. Edstrom A. Venomous and poisonous animals, Krieger Publishing Company, Malabar; 1992.

17. Hoffman DR. Hymenoptera venom proteins. J Nat Toxins 1996;2:169-86.

18. Lima P RM, Brochetto Braga MR, Chaud Neto J. Proteolytic activity of africanized honeybee (Apis mellifera: hymenoptera, Apidae) venom. J Venom Anim Toxins 2000;6:64-76.

19. Haim B, Rimon A, Ishay JS, Rimon S. Purification, characterization and anticoagulant activity of a proteolytic enzyme from Vespaorientalis venom. Toxicon 1999;37:825-9.

20. Schmidt JO. Venoms of the hymenoptera. Piek T. ed. Academic Press: London; 1986. p. 425-508.

21. Sousa JRF, Monteiro RQ, Castro HC, Zingali RB. Proteolytic action of Bothropsjararaca venom upon its own constituents. Toxicon 2001;39:787-92.
22. Hoffman DR, Jacobson RS. Allergens in hymenoptera venom XXVII: bumblebee venom allergy and allergens. J Allergy Clin Immunol 1996;97:812-21.

23. Koh Y, Chung K, Kim D. Biochemical characterization of a thrombin-like enzyme and a fibrinolyticserine protease from snake (Agkistrodon saxatilis) venom. Toxicon 2001;39:555-60.

24. Michelutti KB, Antonialli Junior WF, Batistote M, Cardoso CA. Chemical signatures in the developmental stages of exigua. Genet Mol Res 2016;15:gmr7586.

25. Ho CL, Ko JL. Hornetin: the lethal protein of the hornet (Vespa havitrsus) venom. FEBS Lett 1986;209:18-22.

26. Humblet Y, Sonnet J, Van Y, Persele de Strihou C. Bee sting and acute tubular necrosis. Nephron 1982;31:187-8.

27. Schumacher MJ, Schmidt JO, Egen NB, Lowry JE. Quantity, analysis, and lethality of European-and Africanized honey bee venoms. Am J Trop Med Hyg 1990;3:79-86.

28. Youloten LJF, Atkinson BA, Lee TH. The incidence and nature of adverse reactions to injection immunotherapy in bee and wasp venom allergy. Clin Exp Allergy 1995;25:159-65.

29. Sherman R. What physicians should know about Africanized honeybees. West J Med 1995;163:541-6.

30. Schmidt JO. Toxicology of venoms from the honeybee genus Apis. Toxicon 1995;33:917-27.

31. Golden DB. Insect sting allergy and venom immunotherapy. Ann Allergy Asthma Immunol 2006;96:16-21.

32. Sasvary T, Mueller U. Deaths from insect stings in switzerland 1978-1987. Schweizerische Medizinische Wochenschrifit 1994;124:1887-94.

33. Jones RG, Corteling RL, Bhogal G, Landon J. A novel Fab-based anti-venom for the treatment of mass bee attacks. Am J Trop Med Hyg 1999;61:361-6.

34. Jeannin P, Lecoanet S, Delneste Y, Gauchat JF, Bonnefoy JY. IgE versus IgG4 production can be differentially regulated by IL-10. J Immunol 1998;160:3555-61.

35. Paul BR, Jacob GL, Yunginger JW, Gleich GJ. Comparison of binding of $\operatorname{IgE}$ and IgG antibodies to honeybee venom phospholipase A. J Immunol 1978;120:1917-23.

36. Kemeny DM, Dalton N, Lawrence AJ, Pearce FL, Vernon CA. The purification and characterisation of hyaluronidase from the venom of the honey bee, Apis mellifera. Eur J Biochem 1984;139:217-23.

37. Neuman W, Habermann E, Amend G, Banks BEC, Shipolini RA. Venoms of hymenoptera: biochemical, pharmacological and behavioral aspects. Peak T. ed. Academy Press: London; 1986;3:29-16.

38. Schumacher MJ, Schmidt JO, Egen NB, Lowry JE. Quantity, analysis, and lethality of European and Africanized honey bee venoms. Am J Trop Med Hyg 1990;43:79-86.

39. Habermann E. Bee and wasp venoms. Science 1972;177:31422.

40. Winston ML. The Africanized "killer" bee: biology and public health. Q J Med 1994;87:263-7.

41. Kolecki P. Delayed toxic reaction following massive bee envenomation. Ann Emerg Med 1999;33:114-6.

42. Hossen MS, Shapla UM, Gan SH, Khalil MI. Impact of bee venom enzymes on diseases and immune responses. Molecules 2017;22:25.

43. Welton RE, Williams DJ, Liew D. Injury trends from envenoming in Australia, 2000 2013. Intern Med J 2017;47:170-6.

44. Liu X, Chen D, Xie L, Zhang R. Effect of honeybee venom on proliferation of K1735M2 mouse melanoma cells in vitro and growth of murine B16 melanomas in vitro. J Pharm Pharmacol 2002;54:1083-9.

45. Kularatne SA, Raveendran S, Edirisinghe J, Karunaratne I, Weerakoon K. First reported case of fatal stinging by the large carpenter bee Xylocopa tranquebarica. Wilderness Environ Med 2016;27:2625

46. Kannangare T. GluN2A-/-mice lack bidirectional synaptic plasticity in the dentate gyrus and perform poorly on spatial pattern separation tasks. Cereb Cortex 2015;25:2102-13.

47. Dos santos JA, DE Azevedo Duarte L. Otero IV production of laccase, manganese peroxidase and lignin peroxidase by Brazilian marine derived fungi. Enzymemicrobtechnol 2010;46:32-7. 
48. Perez Riverol A, Dos Santos Pinto JRA, Lasa AM, Palma MS, Brochetto Braga MR. J Proteomics 2017;161:88-103.

49. Orsolic N. Bee venom in cancer therapy. Cancer Metastasis Rev 2012;31:173-94.

50. Hackethal A, Schmidt K. Bee venom therapy, bee venom acupuncture of apiculture: what is the evidence behind the various health claims? Am Bee J 2005;145:665-8.

51. Lee WR, Pak SC, Park KK. The protective effect of bee venom on fibrosis causing inflammatory diseases. Toxins (Basel) 2015; 7:4758-72.

52. Heinen TE, AB Gorini da Veiga. Arthropoda venoms and cancer. Toxicon 2011;57:497-11.

53. Kachel HS, Buckingham SD, Sattelle DB. Insect toxins-selective pharmacological tools and drug/chemical leads. Curr Opin Insect Sci 2018;30:93-8.

54. Lee JA, Son MJ, Choi J, Jun JH, Kim JI, Lee MS. Bee venom acupuncture for rheumatoid arthritis: A systematic review of randomized clinical trials. Br Med J Open 2014;4:e006140.

55. Seo BK, Lee JH, Sung WS, Song EM, Jo DJ. Bee venom acupuncture for the treatment of chronic low back pain: study protocol for a randomized, double-blinded, sham-controlled trial. Trials 2013;14:16.

56. Seo BK, Lee JH, Kim PK, Baek YH, Jo DJ, Lee S. Bee venom acupuncture, NSAIDs or combined treatment for chronic neck pain: study protocol for a randomized, assessor-blind trial. Trials 2014;15:132.

57. Rueff F, Mosbech H, Bonifazi F, Oude Elberink JNG. EAACI interest group on insect venom hypersensitivity diagnosis of hymenoptera venom allergy. Allergy 2005;60:1339-49.

58. Raghuraman H, Chattopadhyay A. Melittin: a membrane-active peptide with diverse functions. Biosci Rep 2007;27:189-23.

59. Damianoglou A, Rodger A, Pridmore C, Dafforn TR, Mosely JA, Sanderson JM, et al. The synergistic action of melittin and phospholipase A2 with lipid membranes: development of linear dichroism for membrane-insertion kinetics. Protein Pept Lett 2010;17:1351-62.

60. Vila Farres X, Giralt E, Vila J. Update of peptides with antibacterial activity. Curr Med Chem 2012;19:6188-98.

61. Blondelle SE, Houghten RA. Hemolytic and antimicrobial activities of the twenty-four individual omission analogues of melittin. Biochemistry 1991;30:4671-8.

62. Dempsey CE. The actions of melittin on membranes. Biochim Biophys Acta 1990;1031:143-61.

63. Boman HG, Wade D, Boman IA, Wahlin B, Merrifield RB. Antibacterial and antimalarial properties of peptides that are cecropin-melittin hybrids. FEBS Lett 1989;259:103-6.

64. Merrifield RB, Juvvadi P, Andreu D, Ubach J, Boman A, Boman HG. Retro and retroenantio analogs of cecropin-melittin hybrids. Proc Natl Acad Sci USA 1995;92:3449-53.

65. Merrifield RB, Wade D, Boman HG. Antibiotic peptides containing D-amino acids. US5585353A; 1996.

66. Anju G, Reetu G, Sudarshan K. Hanbook of research on diverse applications of nanotechnology in biomedicine, chemistry, and engineering. Soni, Shivani: Hershey PA, USA; 2015.

67. Stockwell VO, Duffy B. Use of antibiotics in plant agriculture. Rev Sci Tech 2012;31:199-21079.

68. Badosa E, Ferre R, Planas M, Feliu L, Besalu E, Cabrefiga J, et al. A library of linear undecapeptides with bactericidal activity against phyto-pathogenic bacteria. Peptides 2007;28:2276-85.

69. Rubner MF, Yang SY, Qiu Y, Lynn C, Lally JM. Method for making medical devices having antimicrobial coatings thereon. US20140112994. 2014. Toxins 2015;7:1126-50.

70. Baghian A, Jaynes J, Enright F, Kousoulas KG. An amphipathic alpha-helical synthetic peptide analogue of melittin inhibits herpes simplex virus-1 (HSV-1)-induced cell fusion and virus spread. Peptides 1997;18:177-83.

71. Wachinger M, Saermark T, Erfle V. Influence of amphipathic peptides on the HIV-1 production in persistently infected $\mathrm{T}$ lymphoma cells. FEBS Lett 1992;309:235-41.

72. Hagenbucher S, Eisenring M, Meissle M, Romeis J. Interaction of transgenic and natural insect resistance mechanisms against Spodoptera littoralis in cotton. Pest Manag Sci 2017;73:1670-8.

73. Ariane F Lacerda, Patrícia B Pelegrini, Daiane M de Oliveira, Erico AR Vasconcelos, Maria F Grossi-de-Sa. Anti-parasitic peptides from arthropods and their application in drug therapy. Front Microbiol 2016;7:91.

74. Elias Ferreira SabiaJunior, Luis Felipe Santos Menezes, Israel Flor Silva de Araujo, Elisabeth Ferroni Schwartz. Natural occurrence in venomous arthropods of antimicrobial peptides active against protozoan parasites. Toxins (Basel) 2019;11:563.

75. Victoria Carter, Ann Underhill, Ibrahima Baber, Lakamy Sylla, Mounirou Baby, Isabelle Larget Thiery, Agnes Zettor, et al., Killer bee molecules: antimicrobial peptides as effector molecules to target sporogonic stages of Plasmodium. PLoS Pathog 2013. https://doi.org/10.1371/journal.ppat.1003790

76. Nuno Vale, Luisa Aguiar, Paula Gomes. Anti-microbial peptides: a new class of antimalarial drugs? Front Pharmacol 2014;5:275.

77. Moreau SJ, Asgari S. Venom proteins from parasitoid wasps and their biological functions. Toxins (Basel) 2015;7:2385-412.

78. Dotimas EM, Hamid KR, Hider RC, Ragnarsson U. Isolation and structure analysis of bee venom mast cell degranulating peptide. Biochim Biophys Acta 1987;911:285-93.

79. Ziai MR, Russek S, Wang HC, Beer B, Blume AJ. Mast cell degranulating peptide: a multi-functional neurotoxin. J Pharm Pharmacol 1990;42:457-61.

80. Sharma JN. Basic and clinical aspects of bradykinin receptor antagonists. Prog Drug Res 2014;69:1-14.

81. Shkenderov S, Koburova K. Adolapin-a newly isolated analgetic and anti-inflammatory polypeptide from bee venom. Toxicon 1982;20:317-21.

82. Kitamura H, Yokoyama M, Akita H, Matsushita K, Kurachi Y, Yamada M. Tertiapin potently and selectively blocks muscarinic $\mathrm{K}^{+}$channels in rabbit cardiac myocytes. J Pharmacol Exp Ther 2000;293:196-205.

83. Vlasak R, Kreil G. Nucleotide sequence of cloned cDNAs coding for preprosecapin, a major product of queen-bee venom glands. Eur J Biochem 1984;145:279-82.

84. Meng Y, Yang XX, Zhang JL, Yu DQ. A novel peptide from Apismellifera and solid-phase synthesis of its analogue. Chin Chem Lett 2012;23:1161-64.

85. Mourelle D, Brigatte P, Bringanti LD, de Souza BM, Arcuri HA, Gomes PC, et al. Hyperalgesic and edematogenic effects of Secapin-2, a peptide isolated from Africanized honeybee (Apismellifera) venom. Peptides 2014;59:42-52.

86. Gauldie J, Hanson JM, Shipolini RA, Vernon CA. The structures of some peptides from bee venom. Eur J Biochem 1978;83:405-10.

87. Vick JA, Shipman WH, Brooks RJr. Beta adrenergic and antiarrhythmic effects of cardiopep, a newly isolated substance from whole bee venom. Toxicon 1974;12:139-44.

88. Monsalve RI, Lu G, King TP. Expressions of recombinant venom allergen, antigen 5 of yellowjacket (Vespula vulgaris) and paper wasp (V. annularis), in bacteria or yeast. Protein Expr Purif 1999;16:410-6

89. Konno K, Hisada M, Fontana R, Lorenzi CC, Naoki H, Itagaki Y, et al. Anoplin, a novel antimicrobial peptide from the venom of the solitary wasp Anopliussamariensis. Biochim Biophys Acta 2001;1550:70-80

90. Krishnakumari V, Nagaraj R. Antimicrobial and hemolytic activities of crabrolin, a 13-residue peptide from the venom of the European hornet, Vespa crabro, and its analogs. J Pept Res 1997;50:88-93.

91. Konno K, Rangel M, Oliveira JS, Dos Santos Cabrera MP, Fontana R, Hirata IY, et al. Decoralin, a novel linear cationic alpha-helical peptide from the venom of the solitary eumenine wasp Oreumenesdecoratus. Peptides 2007;28:2320-7.

92. Konno K, Hisada M, Naoki H, Itagaki Y, Fontana R, Rangel M, et al. Eumenitin, a novel antimicrobial peptide from the venom of the solitary eumenine wasp Eumenes rubronotatus. Peptides 2006;27:2624-31.

93. Cerovsky V, Hovorka O, Cvacka J, Voburka Z, Bednarova L, Borovickova $L$, et al. A novel antimicrobial peptide from the venom of the cleptoparasitic bee Melecta albifrons. Chembiochem 2008;9:2815-21.

94. Chionis K, Kostas Chionis, Dimitrios Krikorian, Anna Irini Koukkoun, Maria Sakarellos Daitsiotis, et al. Synthesis and biological activity of lipophilic analogs of the cationic antimicrobial active peptide anoplin. J Pept Sci 2016;22:731-6. 
95. Primon Barros M, Animal Venom. Peptides: potential for new antimicrobial agents. Jose Macedo A. Curr Top Med Chem 2017;17:1119-56.

96. Kim Y, Yangseon Kim, Minky Son, Eun Young Noh, Soonok Kim, Changmu Kim, et al. MP-V1 from the venom of social wasp Vespula vulgaris Is a de novo type of mastoparan that displays superior antimicrobial activities; 2016.

97. Xinwang Yang, Ying Wang,Wen Hui Lee, Yun Zhang. Antimicrobial peptides from the venom gland of the social wasp Vespa Tropica. Toxicon 2013;74:151-7.

98. Jia F, Wang J, Peng J, Zhao P, Kong Z, Wang K, et al. D-amino acid substitution enhances the stability of antimicrobial peptide polybia-CP. Acta Biochim Biophys Sin (Shanghai) 2017;49:916-25.

99. Pak SC. An introduction to the toxins special issue on bee and wasp venoms: Biological characteristics and therapeutic application. Toxins (Basel); 2016

100. Moreno M, Giralt E. Three valuable peptides from bee and wasp venoms for therapeutic and biotechnological use: melittin, apamin and mastoparan. Toxins (Basel) 2015;7:1126-50.

101. Sample CJ, Hudak KE, Barefoot BE. A mastoparan-derived peptide has broad-spectrum antiviral activity against enveloped viruses. Peptides 2013;48:96-105.

102. Wehbe R, Frangieh J, Rima M, El Obeid D, Sabatier JM, Fajloun Z. Bee venom: overview of main compounds and bioactivities for therapeutic interests. Molecules 2019;24:2997.

103. Memariani H, Memariani M, Moravvej H, Shahidi Dadras M. Melittin: a venom-derived peptide with promising anti-viral properties. Eur J Clin Microbiol Infect Dis 2020;39:5-17.

104. Agarwal G, Gabrani R. Antiviral peptides: identification and validation. Int J Pept Res Ther 2020;18:1-20.

105. Roskens VA, Carpenter JM, Pickett KM, Ballif BA. Preservation of field samples for enzymatic and proteomic characterization: analysis of proteins from the trophallactic fluid of hornets and yellow jackets. J Proteome Res 2010;9:5484-91.

106. Gonçalves J, Rangel M, Biolchi A, Alves E, Moreira K, Silva L, et al. Antinociceptive properties of the mastoparan peptide agelaia-MPI isolated from social wasps. Toxicon 2016;120:15-21.

107. Pucci L, Lucchesi D, Fotino C, Grupillo M, Miccoli R, Penno G, et al. Il polimorfismo PlA1/PIA2 dell'integrina Beta 3 non contribuisce al rischio di complicanze micro-e macrovascolarineldiabetetipo 1 e tipo 2 [Integrin Beta 3 PlA1/PlA2 polimorphism does not contribute to complications in both type 1 and type 2 diabetes]. $\mathrm{G}$ Ital Nefrol 2003;20:461-9.

108. Del Prato S, Tiengo A. The importance of first-phase insulin secretion: implications for the therapy of type 2 diabetes mellitus. Diabetes Metab Res Rev 2001;17:164-74.

109. Sarmiento BE, Santos Menezes LF, Schwartz EF. Insulin release mechanism modulated by toxins isolated from animal venoms: from basic research to drug development prospects. Molecules 2019;24:1846.

110. Hou, June Chunqiu. Insulin granule biogenesis, trafficking and exocytosis. Vitam Horm 2009;80:473-506.

111. Melo da Cunha JDS, Alfredo TM, Dos Santos JM, Alves Junior VV, Rabelo LA, Lima ES, et al. Antioxidant, anti-hyperglycemic, and anti-diabetic activity of Apis mellifera bee tea. PLoS One 2018. https://doi.org/10.1371/journal.pone.0197071

112. Mousavi SM, Imani S, Haghighi S, Mousavi SE, Karimi A. Effect of Iranian honey bee (Apis mellifera) venom on blood glucose and insulin in diabetic rats. J Arthropod Borne Dis 2012;6:136-43.

113. Saba E, Shafeeq T, Irfan M. Anti-inflammatory activity of crude venom isolated from parasitoid wasp, Bracon hebetor say. Mediators Inflamm 2017;697:81-94.

114. Seabrooks L, Hu L. Insects: an underrepresented resource for the discovery of biologically active natural products. Acta Pharm Sin B 2017;7:409-26.

115. Bordon KCF, Cologna CT, Fornari Baldo EC. From animal poisons and venoms to medicines: achievements, challenges and perspectives in drug discovery. Front Pharmacol 2020;11:1132.

116. Cheon SY, Chung KS, Roh SS, Cha YY, An HJ. Bee venom suppresses the differentiation of preadipocytes and high fat diet-induced obesity by inhibiting adipogenesis. Toxins (Basel) 2018;10:9.

117. Mars J Yang, Wen Yuh Lin, Kuang Hui Lu, Wu Chun Tu. Evaluating anti-oxidative activities of amino acid substitutions on mastoparan-B. Peptides 2011;32:2037-43.
118. Jose Palmieri M, Ribeiro Barroso A, Fonseca Andrade Vieira L, Monteiro MC, Martins Soares A, Souza Cesar PH, et al. L. occidentalis and Polybia fastidiosa venom: a cytogenotoxic approach of effects on human and vegetal cells. Drug Chem Toxicol 2019. DOI:10.1080/01480545.2019.1631339

119. Schwartz EF, Elisabeth F Schwartz, Caroline BF Mourao, Karla G Moreira, Thalita S Camargos, et al. Arthropod venoms: a vast arsenal of insecticidal neuropeptide. Biopolymers 2012;98:385405 .

120. Henry TJ. Revision of the plant bug genus tytthus (hemiptera, heteroptera, miridae, phylinae). Zookeys 2012;220:1-114.

121. Kazuma K, Kohei Kazuma, Kenji Ando, Ken-Ichi Nihei, Xiaoyu Wang. Peptidomic analysis of the venom of the solitary bee Xylocopa Appendiculata circumvolans. J Venom Animal Toxins Incl Trop Dis 2017;23:40.

122. Lopes KS, Kamila Soares Lopes, Gabriel Avohay, Alves Campos, Luana Cristina Camargo, Adolfo Carlos Barros de Souza, et al., Characterization of two peptides isolated from the venom of social wasp Chartergellus communis (Hymenoptera: Vespidae): influence of multiple alanine residues and c-terminal amidation on biological effects. Peptides 2017;95:84-93.

123. Deuis JR, Jennifer R Deuis, Alexander Mueller, Mathilde R Israel, Irina Vetter. The pharmacology of voltage-gated sodium channel activator. Neuropharmacology 2017;127:87-108.

124. Welton RE, Williams DJ, Liew D. Injury trends from envenoming in Australia, 2000-2013. Intern Med I 2017;47:170-6.

125. Graler $M H$, Goetzl EJ. Lysophospholipids and their G proteincoupled receptors in inflammation and immunity. Biochim Biophys Acta 2002;1582:168-74.

126. Doery HM, Pearson JE. Phospholipase B in snake venoms and bee venom. Biochem J 1964;92:599-602.

127. Girish KS, Kemparaju K. The magic glue hyaluronan and its eraser hyaluronidase: a biological overview. Life Sci 2007;80:1921-43.

128. Uzair B, Bushra Uzair, Rabia Bushra, Barkat AliKhan, Sarwat Zareen, Fehmida Fasim. Potential uses of venom proteins in treatment of HIV. Protein Pept Lett 2018;25:619-25.

129. Mendes MA, De Souza BM, Marques MR, Palma MS. Structural and biological characterization of two novel peptides from the venom of the neotropical social wasp Agelaia pallipes pallipes. Toxicon 2004;44:67-74.

130. Han SM, Lee KG, Pak SC. Effects of cosmetics containing purified honeybee (Apis mellifera L.) venom on acne vulgaris. J Integr Med 2013;11:320-6.

131. Cho SY, Shim SR, Rhee HY, Park HJ, Jung WS, Moon SK, et al. Effectiveness of acupuncture and bee venom acupuncture in idiopathic Parkinson's disease. Parkinsonism Relat Disord 2012;18:948-52.

132. Alves EM, Heneine LGD, Pesquero JL, Albuquerque MLD. Pharmaceutical composition containin an apitoxin fraction and use there of W02011041865; 2011;7:1126-15.

133. Lee MS, Pittler MH, Shin BC, Kong JC, Ernst E. Bee venom acupuncture for musculoskeletal pain: a review.J Pain 2008;9:289-97.

134. Huh J, Kang JW, Nam D, Baek YH, Choi DY, Park DS, et al. Melittin suppresses VEGF-a-induced tumor growth by blocking VEGFR-2 and the COX-2-mediated MAPK signaling pathway. J Nat Prod 2012;75:1922-9.

135. Yang X, Zhu H, Ge Y, Liu J, Cai J, Qin Q et al. Melittin enhances radiosensitivity of hypoxic head and neck squamous cell carcinoma by suppressing HIF-1alpha. Tumour Biol 2014;35:10443-8.

136. Dunn RD, Weston KM, Longhurst TJ, Lilley GG, Rivett DE, Hudson PJ, et al. Antigen binding and cytotoxic properties of a recombinant immunotoxin incorporating the lytic peptide, melittin. Immunotechnology 1996;2:229-40.

137. Zhao X, Yu Z, Dai W, Yao Z, Zhou W, Zhou W, et al. Construction and characterization of an anti-asialoglycoproteinreceptor single-chain variable-fragment-targeted melittin. Biotechnol Appl Biochem 2011;58:405-11.

138. Jin H, Li C, Li D, Cai M, Li Z, Wang S, et al. Construction and characterization of a CTLA-4-targeted scFV-melittin fusion protein as a potential immune suppressive agent for organ transplant. Cell Biochem Biophys 2013;67:1067-74. 
139. Holle L, Song W, Holle E, Wei Y, Wagner T, Yu X. A matrix metalloproteinase 2 cleavable melittin/avidin conjugate specifically targets tumor cells in vitro and in vivo. Int J Oncol 2003;22:93-8.

140. Holle L, Song W, Holle E, Wei Y, Li J, Wagner TE, et al. In vitroand in vivo-targeted tumor lysis by an MMP2 cleavable melittin-LAP fusion protein. Int J Oncol 2009;35:829-35.

141. Yang L, Cui F, Shi K, Cun, Wang R. Design of high payload PLGA nanoparticles containing melittin/sodium dodecyl sulfate complex by the hydrophobic ion-pairing technique. Drug Dev Ind Pharm 2009;35:959-68.

142. Hu H, Chen D, Liu Y, Deng Y, Yang S, Qiao M, et al. Target ability and therapy efficacy of immune liposomes using a humanized anti-hepatoma disulfide-stabilized Fv fragment on tumor cells. J Pharm Sci 2006;95:192-9.

143. Barrajon Catalan, Menendez Gutierrez MP, Falco A, Carrato A, Saceda M, Micol V. Selective death of human breast cancer cells by lytic immune liposomes: correlation with their HER2 expression level. Cancer Lett 2010;290:192-203.

144. Popplewell JF, Swann MJ, Freeman NJ, McDonnell C, Ford RC. Quantifying the effects of melittin on liposomes. Biochim Biophys Acta 2007;1768:13-20.

145. Soman NR, Lanza GM, Heuser JM, Schlesinger PH, Wickline SA. Synthesis and characterization of stable fluorocarbon nanostructures as drug delivery vehicles for cytolytic peptides. Nano Lett 2008;8:1131-6.

146. Soman NR, Baldwin SL, Hu G, Marsh JN, Lanza GM, Heuser JE, et al. Molecularly targeted nanocarriers deliver the cytolytic peptide melittinspecifically to tumor cells in mice, reducing tumor growth. J Clin Investig 2009;119:2830-42.

147. Schaper S, Wendt H, Bamberger J, Sieber V, Schmid J, Becker A. A bi-functional UDP-sugar 4-epimerase supports biosynthesis of multiple cell surface polysaccharides in Sinorhizobium meliloti. J Bacteriol 2019;201:801-18.

148. Müller UR. Bee venom allergy in beekeepers and their family members. Curr Opin Allergy ClinImmunol 2005;5:343-7.

149. Muller UR. Hymenoptera venom proteins and peptides for diagnosis and treatment of venom allergic patients. Inflamm Allergy Drug Targets 2011;10:420-8.

150. Heppt MV, Clanner Engelshofen BM, Marsela E, Wessely A, Kammerbauer C, Przybilla B, et al. Comparative analysis of the phototoxicity induced by BRAF inhibitors and alleviation through antioxidants. Photodermatol Photoimmunol Photomed 2020;36:126-34.

151. Becerril Angeles M, Nunez Velazquez M, Marin Martinez J, Grupo del Programa, Nacional de Control de la Abeja, Africanizada SAGARPA. Valoracion median epruebascutaneas de la hipersensibilidad al veneno de abeja en apicultores [Assessment of hypersensitivity to honey-bee venom in beekeepers by skin tests]. Rev Alerg Mex 2013;60:164-7.

152. Munstedt K. Using bee products for the prevention and treatment of oral mucositis induced by cancer treatment. Molecules 2019;24:3023.

153. Wu TM, Li ML. The cytolytic action of all-D mastoparan M on tumor cell lines. Int J Tissue React 1999;21:35-42.

154. Wu CW, Kirshenbaum K, Sanborn TJ, Patch JA, Huang K, Dill KA, et al. Structural and spectroscopic studies of peptoid oligomers with alpha-chiral aliphatic side chains. J Am Chem Soc 2003;125:13525-30.

155. Hussein AA, Nabil ZI, Zalat SM, Rakha MK. Comparative study of the venoms from three species of bees: effects on heart activity and blood. J Nat Toxins 2001;10:343-57.

156. Lambeau G, Ancian P, Nicolas JP, Beiboer SH, Moinier D, Verheij $\mathrm{H}$, et al. Structural elements of secretory phospholipases A2 involved in the binding to M-type receptors. J Biol Chem 1995;270:5534-40.

157. Christen V, Mittner F, Fent K. Molecular effects of neonicotinoids in honey bees (Apis mellifera). Environ Sci Technol 2016;50:4071-81.

158. Mohammed SEA, Kabbashi AS, Koko WS, Ansari MJ, Adgaba N, Al-Ghamdi A. In vitro activity of some natural honeys against Entamoeba histolytica and Giardia lamblia trophozoites. Saudi J Biol Sci 2019;26:238-43.

159. Ahmad F, Seerangan P, Mustafa MZ, Osman ZF, Abdullah JM, Idris Z. Anti-cancer properties of Hetero trigonaitama sp. honey via Induction of apoptosis in malignant glioma cells. Malays J Med Sci 2019;26:30-9.

160. Shiassi Arani F, Karimzadeh L, Ghafoori SM, Nabiuni M. Antimutagenic and synergistic cytotoxic effect of cisplatin and honey bee venom on $4 \mathrm{~T} 1$ invasive mammary carcinoma cell line. Adv Pharmacol Sci 2019;758:13-8.

161. Seyhan MF, Yılmaz E, Timirci Kahraman O, Saygllı N, Kisakesen $\mathrm{HI}$, Eronat AP, et al. Anatolian honey is not only sweet but can also protect from breast cancer: elixir for women from artemis to present. IUBMB Life 2017;69:677-88.

162. Uddin MB. Inhibitory effects of bee venom and its components against viruses in vitro in vivo. J Microbiol 2016;54:853-66.

163. Brudzynski K. Antibacterial compounds of canadian honeys target bacterial cell wall inducing phenotype changes, growth inhibition and cell lysis that resemble action of $\beta$-Lactam. Antibiotics 2014;9:e106967.

164. Kustiawan PM. In vitro cytotoxicity of Indonesian stingless bee products against human cancer cell lines. J Trop Biomed 2014;4:549-56.

165. Moskwa J. Polish natural bee honeys are anti-proliferative and anti-metastatic agents in human glioblastoma multiforme U87MG cell line. PLOS ONE 2014. https://doi.org/10.1371/journal.pone.0090533

166. Park D. Chemotherapy resistance in diffuse-type gastric adenocarcinoma is mediated by RhoA activation in cancer stem-like cells. Clin Cancer Res 2016;22:971-83.

167. Panda S, I Ehsan. Molecular docking studies of snake venom serine protease of sharp-nosed pit viper with hesperetin. Asian J Pharm Clin Res 2018;11:457-61.

168. Hymenoptera-Wikipedia. Available from: https://en.wikipedia.org/wiki/Hymenoptera [Last accessed on 05 Nov 2020]

169. Hymenopteran | insect | Britannica. Available from: www.britannica.com [Last accessed on 05 Nov 2020]

170. Donald R. Hoffman, in encyclopedia of immunology. (Second Edition); 1998.

171. Baek JH, Lee SH. Identification and characterization of venom proteins of two solitary wasps. Toxicon 2010;56:554-62.

172. Kumar RB, MX Suresh. Neurotox: a unique database for animal neurotoxins. Int J Pharm Pharm Sci 2015;7:351-4.

173. Preet P. Peptides: a new therapeutic approach. Int J Curr Pharm Res 2018;10:29-34.

174. Baek JH, Woo TH, Kim CB. Differential gene expression profiles in the venomgland/sac of Orancistrocerus drewseni (Hymenoptera: Eumenidae). Arch Insect Biochem Physiol 2009;71:205-22.

175. Baek JH, Lee SH. Differential gene expression profiles in the venom gland/sac of Eumenes pomiformis (Hymenoptera: Eumenidae). Toxicon 2010;55:1147-56.

176. Dos Santos LD, Santos KS, Pinto JRA. Profiling the proteome of the venom from the social wasp Polybia paulista: a clue to understand the envenoming mechanism. J Proteome Res 2010;9:3867-77.

177. Liu ZR, Chen SG, Zhou Y. Deciphering the venomicranscriptome of killer-wasp Vespa velutina. Sci Rep 2015;5:9454.

178. Yoon KA, Kim K, Nguyen P. Comparative bioactivities of mastoparans from social hornets Vespa crabro and Vespa analis. J Asia Pac Entomol 2015;18:825-9.

179. Konno K, Hisada M, Itagaki Y. Isolation and structure of pompilidotoxins, novel peptide neurotoxins in solitary wasp venoms. Biochem Biophys Res Commun 1998;250:612-6.

180. Asawale KY, MC Mehta, PSUike. Drug utilization analysis of anti-snake venom at a tertiary care centre in central Maharasthtra: a 3y retrospective study. Asian J Pharm Clin Res 2018;11:134-7.

181. Moreno M, Giralt E. Three valuable peptides from bee and wasp venoms for therapeutic and biotechnological use: melittin, apamin and mastoparan. Toxins (Basel) 2015;7:1126-50. 